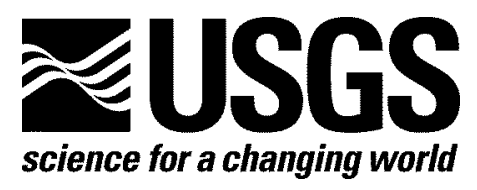

\title{
Geophysical Studies of the Crump Geyser Known Geothermal Resource Area, Oregon, in 1975
}

By Donald Plouff

2006

Open-File Report 2006-1110

U.S. Department of the Interior U.S. Geological Survey 


\section{U.S. Department of the Interior \\ Gale A. Norton, Secretary}

\section{U.S. Geological Survey \\ P. Patrick Leahy, Acting Director}

U.S. Geological Survey, Reston, Virginia 2006

For product and ordering information:

World Wide Web: http://www.usgs.gov/pubprod

Telephone: 1-888-ASK-USGS

For more information on the USGS - the Federal source for science about the Earth,

its natural and living resources, natural hazards, and the environment:

World Wide Web: http://www.usgs.gov

Telephone: 1-888-ASK-USGS

Any use of trade, product, or firm names is for descriptive purposes only and does not imply endorsement by the U.S. Government.

Although this report is in the public domain, permission must be secured from the individual copyright owners to reproduce any copyrighted material contained within this report. 


\section{Contents}

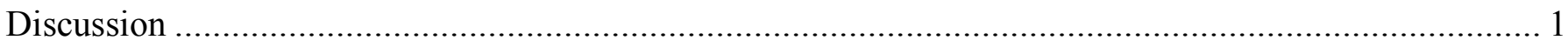

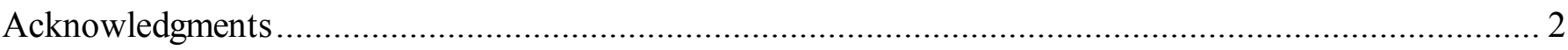

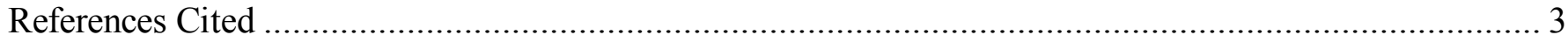

Appendix 1-Administrative report, June 17,1975 ................................................................. attached

Appendix 2-Reprint of NTIS publication PB-245-426/AS........................................................ attached 


\title{
Geophysical Studies of the Crump Geyser Known Geothermal Resource Area, Oregon, in 1975
}

\author{
By Donald Plouff
}

\section{Discussion}

The U. S. Geological Survey (USGS) conducted geophysical studies in support of the resource appraisal of the Crump Geyser Known Geothermal Resource Area (KGRA). This area was designated as a KGRA by the USGS, and this designation became effective on December 24, 1970 (Godwin, and others, 1971). The land classification standards for a KGRA were established by the Geothermal Steam Act of 1970 (Public Law 91-581). Federal lands so classified required competitive leasing for the development of geothermal resources.

Donald Plouff presented an administrative report of USGS geophysical studies entitled "Geophysical background of the Crump Geyser area, Oregon, KGRA" to a USGS resource committee on June 17, 1975. This report, which essentially was a description of geophysical data and a preliminary interpretation without discussion of resource appraisal, is in Appendix 1. Reduction of sheets or plates in the original administrative report to page-size figures, which are listed and appended to the back of the text in Appendix 1, did not seem to significantly degrade legibility. Bold print in the text indicates where minor changes were made. A colored page-size index and tectonic map, which also show regional geology not shown in figure 2, was substituted for original figure 1. Detailed descriptions for the geologic units referenced in the text and shown on figures 1 and 2 were separately defined by Walker and Repenning (1965) and presumably were discussed in other reports to the committee. Heavy dashed lines on figures 1 and 2 indicate the approximate KGRA boundary

Units of measurement such as miles and feet and corresponding map scales were in the original report, but international units such as meters and kilometers now are preferred. The distance unit "meter" originally was spelled "metre" in Appendix 1 in accordance with the conventional international and USGS usage in 1975. For conversion to Standard International Units:

$$
\begin{aligned}
& 1 \text { foot }=0.3048 \text { meter } \\
& 1 \text { mile }=1.609 \text { kilometer } \\
& 1 \mathrm{~g} / \mathrm{cm}^{3}=1,000 \mathrm{~kg} / \mathrm{m}^{3} \\
& 1 \text { gamma }=1 \text { nanotesla }
\end{aligned}
$$

One of the principal results of the geophysical studies was to obtain a gravity map (Appendix 1, fig. 10; Plouff, and Conradi, 1975, pl. 9), which reflects the fault-bounded steepness of the west edge of sediments and locates the maximum thickness of valley sediments at about 10 kilometers south of Crump Geyser. Based on the indicated regional-gravity profile and density-contrast assumptions for the 
two-dimensional profile, the maximum sediment thickness was estimated at 820 meters. A threedimensional gravity model would have yielded a greater thickness. Audiomagnotelluric measurements were not made as far south as the location of the gravity low, as determined in the field, due to a lack of communication at that time. A boat was borrowed to collect gravity measurements along the edge of Crump Lake, but the attempt was curtailed by harsh, snowy weather on May 21, 1975, which shortly followed days of hot temperature.

Most of the geophysical data and illustrations in Appendix 1 have been published (Gregory and Martinez, 1975; Plouff, 1975; and Plouff and Conradi, 1975), and Donald Plouff (1986) discussed a gravity interpretation of Warner Valley at the Fall 1986 American Geophysical Union meeting in San Francisco. Further interpretation of possible subsurface geologic sources of geophysical anomalies was not discussed in Appendix 1. For example, how were apparent resistivity lows (Appendix 1, figs. 3-6) centered near Crump Geyser affected by a well and other manmade electrically conductive or magnetic objects? What is the geologic significance of the 15-milligal eastward decrease across Warner Valley? The explanation that the two-dimensional gravity model (Appendix 1, fig. 14) was based on an inverse iterative method suggested by Bott (1960) was not included. Inasmuch as there was no local subsurface rock density distribution information to further constrain the gravity model, the three-dimensional methodology suggested by Plouff (1976) was not attempted.

Inasmuch as the associated publication by Plouff (1975), which released the gravity data, is difficult to obtain and not in digital format, that report is reproduced in Appendix 2. Two figures of the publication are appended to the back of the text. A later formula for the theoretical value of gravity for the given latitudes at sea level (International Association of Geodesy, 1971) should be used to re-compute gravity anomalies. To merge the observed-gravity values printed in that report with later measurements, an empirically determined constant gravity datum shift should be applied. USGS reports in the Open-File series can be downloaded from the Publication Warehouse at:

http://pubs.er.usgs.gov/pubs/ofr/

\section{Acknowledgments}

Marshall J. Reed suggested that the previously unpublished administrative report, although informally prepared, should be released to the public as a historical record and for possible present day application. He also described how KGRA's fit into the resource appraisal system and greatly simplified my effort by obtaining and scanning original texts, plates, figures, and tables. Frank A. Petrafeso, chief of the aeromagnetic compilation unit in 1975, supplied the unpublished aeromagnetic map. Donald B. Hoover supplied figures and wrote the rough draft of the audiomagnetotelluric text to be incorporated in the administrative report. Carl Long provided further understanding of audiomagnetotelluric methodology. Arhur Conradi, Jr. assisted in the field and office for gravity and ground magnetic studies. Nicholas Voegtly, Water Resources Division, assisted in the field. 


\section{References Cited}

Bott, M.H.P., 1960, The use of rapid digital computing methods for gravity interpretation of sedimentary basins: Geophysical Journal of the Royal Astronomical Society, v. 3, p. 63-67.

Godwin, L.H., Haigler, L.B., Rioux, R.L., White, D.E., Muffler, L.J.P., and Wayland, R.G., 1971, Classification of public land valuable for geothermal steam and associated geothermal resources: U.S. Geological Survey Circular 647, 18 p.

Gregory, D.I., and Martinez, R.J., 1975, Audio-magnetotelluric apparent resistivity maps, southern Warner Valley, Lake County, Oregon: U.S. Geological Survey Open-File Report 75-652, 4 sheets.

International Association of Geodesy, 1971, Geodetic reference system 1967: International Association of Geodesy Special Publication no. 3, 116 p.

Plouff, Donald, 1975, Gravity data in Crump Geyser area, Oregon: National Technical Information Service, PB-245-426, 16 p.

Plouff, Donald, 1976, Gravity and magnetic fields of polygonal prisms and application to magnetic terrain corrections: Geophysics, v. 41, no. 4, p. 727-741

Plouff, Donald, and Conradi, Arthur, Jr., 1975, Gravity and magnetic profiles and maps, Crump Geyser area, Oregon: U.S. Geological Survey Open-File Report 75-346, 2 p., 12 sheets.

Plouff, Donald, 1986, Role of magma in localization of basin-range valleys [abs.]: American Geophysical Union Transactions (Eos), v. 67, no. 44, p. 1226.

Walker, G.W., and Repenning, 1965, Reconnaissance geologic map of the Adel quadrangle, Lake, Harney, and Malheur Counties, Oregon: U.S. Geological Survey Miscellaneous Geologic Investigations Map I-446, 1 sheet. 


\title{
APPENDIX 1-ADMINISTRATIVE REPORT, JUNE 17,1975
}

[Bold print indicates minor modification of original report;

list of figures is on last page of text.]

\author{
Geophysical background of the \\ Crump Geyser, Oregon, K. G. R. A.
}

By

Donald Plouff

U.S. Geological Survey

Menlo Park, California

This report is preliminary and has

not been edited or reviewed for

conformity with Geological Survey

standards and nomenclature. 
The Crump Geyser Known Geothermal Resource Area (Crump Geyser KGRA) is located in Lake county, Oregon. The area of interest extends southward from the north edge of Crump Lake to the south edge of Warner Valley and continues southward to the Nevada border (Figure 1). The town of Adel is located near the center of the area. The occurrence of Crump Geyser at the west central edge of the valley and a hot spring at the northeast edge of the valley indicate potential development as a geothermal resource area.

\section{GEOLOGIC BACKGROUND}

The geologic map of G. W. Walker and C. A. Repenning (1965, Reconnaissance geologic map of the Adel quadrangle, Lake, Harney, and Malheur Counties, Oregon: U.S. Geol. Survey Misc. Geol. Inv. Map I-446) provides the basis for interpretation of the geophysical data collected near the Crump Geyser KGRA. Figure 1 is reproduced from the map of Walker and Repenning, and Figure 2 is enlarged to closely match the 1:62,500 map scale used in the following report. Problems of photographic reproduction, however, resulted in a slightly mismatching scale of about $1: 61,200$.

Warner Valley lies within the Basin and Range province and is a typical faulted basin, elongated in the north-south direction. The mapped surface faults--with upthrown sides to the west--near the west edge of Warner Valley form a fairly continuous north-south belt (Tectonic Sketch Map, Figure 1). The east edge of Warner Valley is bordered by faults with upthrown sides to the east only near the hot springs and a northwest trending fault along the northeast edge of Greaser Reservoir. A fairly continuous, though highly complicated, belt of north trending faults with upthrown sides to the east, however, appears to project southeast and thence southward from the vicinity of the hot springs to join with a fault at the east edge of Coleman Valley.

The mountains surrounding Warner Valley are primarily composed of a thick, complexly-faulted sequence of Tertiary rocks. Three Tertiary rock units are indicated by Walker and Repenning within the area of geophysical surveys. The oldest unit, labeled Tbf, consists of massive basalt flows and minor beds of tuff and scoria. The unit of intermediate age, Tts, mostly consists of fine-grained tuffaceous sedimentary rocks and tuffs. The youngest Tertiary unit, Tb, consists of basalt flows, which generally dip 5 to 10 degrees.

\section{GEOPHYSICAL METHODS USED}

The audio-magnetotelluric method (AMT) is used to map electrically conductive bodies. The method is used in geothermal areas to search for conductivity anomalies associated with hot saline waters and related altered rock. About 20 man-days were spent collecting audio-magnetotelluric data near Warner Valley.

The magnetic method is used to detect changes in the magnetic properties of rocks. The method can be used to detect the location of the continuation of faults beneath alluvium, to detect contacts between rocks of different types, and to determine the thickness of alluvium over magnetic basement rock. Six man-days were spent in the field collecting magnetic data with a continuously-recording, truckborne magnetometer. An aeromagnetic survey was flown to provide more complete coverage of the area. 
The gravity method is used to map geologic bodies on the basis of changes of rock density. The method can be used to estimate the configuration of the bedrock surface beneath alluvial valleys and to determine the location of concealed faults. Twenty-seven man-days were spent in the field collecting gravity data.

\section{AUDIO-MAGNETOTELLURIC SURVEY}

The audio-magnetotelluric (AMT) method is an electromagnetic exploration technique which uses energy derived from world-wide lightning storms to measure variations in earth resistivity as a function of depth and position. The U.S. Geological survey is using AMT methods for reconnaissance surveys in geothermal areas because it is a fairly fast, simple, and effective means of mapping resistivity variations at moderate depths. The depth of exploration is a function of both the frequency of the received signal and the resistivity of the lithologic section. The maximum exploration depth is approximately one skin depth, $\underline{\mathbf{D}}$, which for a homogeneous half-space is given by

$$
\mathbf{D}=503(\mathbf{R} / \mathrm{f})^{1 / 2} \text { meters, }
$$

where $\underline{\boldsymbol{R}}$ is the resistivity in ohmmeters and $\mathrm{f}$ is the frequency in Hertz. This equation can be used to roughly estimate the exploration depths at each AMT station (Figures 3-6), using the frequency for the given map and the apparent resistivity at that station.

The electric component of the electromagnetic field is the time-varying difference of potential between a pair of steel electrodes separated at a distance of 100 meters. The orthogonal, horizontal magnetic component is detected with a sensor that consists of thousands of turns of wire wrapped around a ferrite core. The voltage changes are measured by using matched, narrow-band, selectively-tuned voltmeters. Apparent resistivities were calculated at frequencies centered at 7.5 , 27, and $285 \mathrm{~Hz}$ along components in the north-south and east-west directions.

Each of the four apparent resistivity maps (Figures 3-6) indicates a general resistivity low centered near crump Geyser. Using the four-ohmmeter contour as an arbitrary dividing line, the part of the resistivity low associated with the most conductive underlying rocks encloses a surface area of less than two square kilometers. The low is bounded on the south by a relative resistivity high, which tends to cross Warner Valley at about 3 to $7 \mathrm{~km}$ south of Crump Geyser.

The shapes of the contour lines, especially to the west of Crump Geyser were guided by numerical interpolation rather than by geologic inference. In view of the occurrence of marked geologic changes along the escarpment to the west of crump Geyser, the association of the valley AMT low with a distant station to the west (especially noticeable at $7.5 \mathrm{~Hz}$ ) is unlikely. A closer station spacing, which is infeasible to the west, more likely might result in D-shaped contours that are convex to the east.

The small high south of the prominent low (Figure 5) may indicate a zone of alluvium which has been indurated by an earlier cycle of thermal activity. A small low resistivity nose near the east edge of the valley (Figures 4 and 5) might indicate thermal water rising along a fault.

The apparent resistivity value at the sounding near crump Geyser increases from 1.7 or 1.8 ohmmeters on the $27 \mathrm{~Hz}$ maps to 2.5 ohmmeters on the $7.5 \mathrm{~Hz}$ map (Figure 6). A decrease in frequency is equivalent to an increase in the depth or distance of penetration of the electromagnetic wave. The deeper-penetrating, lower- 
frequency sounding indicates a high resistivity layer at depth or indicates the edge of a relatively narrow conductive zone. The latter interpretation seems likely at this location because the thermal waters leaking to the surface probably are controlled by faulting near the west edge of the valley. The lack of other conductivity anomalies along the fault zone probably indicates that it is sealed to rising thermal waters. The audio-magnetotelluric data indicate that thermal waters in Warner Valley are probably fault-controlled in the upper part of the geologic section, but no extensive shallow reservoir exists within the surveyed area.

\section{MAGNETIC SURVEYS}

\section{Truckborne magnetometer}

Twelve truckborne magnetometer traverses are located near the Crump Geyser area (Figure 7). A fluxgate magnetometer, mounted about four meters above the ground surface, was used to continuously measure the earth's total magnetic field. The original paper chart records of the total field measurements were photographically reduced to a scale of about 1:60,000, which is nearly the same distance scale as other figures of this report. Circled numbers on the magnetic records (Figures 8a8f) refer to location-points on the traverse map (Figure 7).

The scale on the magnetic records is 200 gammas between numbered chart lines. Datum shifts caused by rapid changes of the magnetic field often were needed to maintain the pen position between chart lines numbered 0 to 12 . The closest fourdigit push-button setting (pbs) number indicated to the right of a record section is used to convert amplitudes on the chart, in terms of interpolated chart line numbers, $\underline{N}$, to values of the absolute total magnetic field, $\underline{T}$ (in gammas). The conversion formula is

$$
\mathrm{T}=48,200+200 \mathrm{~N}+2000 \mathrm{P}_{1}+400 \mathrm{P}_{2}+100 \mathrm{P}_{3}+20 \mathrm{P}_{4},
$$

where $\mathrm{P}_{1}$ to $\mathrm{P}_{4}$ are the respective digits in a left-to-right sequence for the push button setting.

Man-made objects such as culverts, bridges, vehicles, and cattle-guards produce sharp spikes on the magnetic record, which interfere with recognition of anomalies that result from geologic changes. The instrument operator has crossed out all of the anomalies that are caused by recognized man-made objects, but others may remain undetected.

The magnetic profiles (Figures 8a-8f) have been annotated to indicate the locations of possible faults or geologic contacts. The interpretation of these locations is based on a change in character along the magnetic record. The change in character is denoted as a local shift of magnetic level, "L", a change of wave amplitude, "A", or a change of wavelength (average horizontal distance between magnetic peaks or troughs), "W". The letter "G" denotes a gradual change, such as a gently dipping contact. Changes from short to long wavelength anomalies indicate an increase in depth to underlying magnetic rocks, a decrease of large scale heterogeneity of magnetization of the rocks, or an increase in lateral distance of the sensor from nearby magnetic rocks due to change of road direction or topography. Shorter wavelengths anomalies also can be observed along roads near steel fences (Figure 8b) or over road fill that consists of crushed magnetic rock.

A decrease of wavelength results from increasing depth of magnetic rocks beneath alluvium. Thus, a commonly-used estimate of the maximum thickness of alluvium (depth to the top of magnetic rock) can be made by measuring the 
horizontal extent of the steepest gradient associated with magnetic anomalies. Magnetometer traverses in Warner Valley, however, provided only six locations farther than a horizontal distance of one kilometer from Tertiary rock, where a possible depth estimate could be made. Several maximum-depth-estimates can be made near the edge of Warner Valley (at interpolated location numbers 15.3, 68.6, 73.5, 74.6, and 76.3) with the thickness of alluvium ranging to 500 feet and in Coleman Valley (at location numbers 38.7, 39.8, and 40.2 in Figures 7 and 8b) with thicknesses of less than 200 feet.

The entire length of traverse W1 (Figures 7 and 8a, and 11) along the main highway across Warner Valley indicates the shortest wavelength background signal of all traverses across Warner or Coleman Valleys. Perhaps much of high frequency content can be related to man-made interference such as culverts, magnetic road fill, power lines, and the steel reflector posts that occur at intervals of 0.1 mile. Except for Coleman Valley, the alluvium may be thinner along the highway than at other valley locations. The occurrence of an audio-magnetotelluric high near the highway also tends to indicate a minimum thickness of alluvium there. The occurrence of step-like magnetic features, a major fault at the edge of the valley, a general decrease of magnetic level to the west, and the absence of high amplitude anomalies tend to indicate a large thickness of alluvium along the highway.

According to the amplitudes of magnetic anomalies recorded near the edge of and outside Warner Valley, the Tertiary rocks are highly magnetic. One would expect that the amplitude of magnetic anomalies caused by Tertiary rocks underlying thin alluvial cover not to be greatly decreased. Short wavelength anomalies superimposed on longer wavelength, higher amplitude anomalies such as near the west edge of Coleman Valley (near location-point 39, Figure 8b) would be expected. But the short wavelength anomalies along the highway, where depth estimates would be less than 200 feet, are of relatively small amplitude (less than 100 gammas). Therefore, if the alluvium is thin along the highway, the magnetization of the underlying rock would be unusually low or, possibly, unusually homogeneous compared to other Tertiary rock in the area.

Aeromagnetic survey

The aeromagnetic map (Figure 9) provides information to fill in the gaps of the truck-mounted magnetometer survey and permits a view of the regional magnetic background near the crump Geyser area with less interference from local anomalies than the ground level survey. The truckborne magnetometer survey, however, provides more accurate locations and depth estimates. Note that not only are the amplitudes of aeromagnetic anomalies smaller than the equivalent ground level anomalies but, because of the inclination of the earth's field, the locations of the aeromagnetic anomalies are shifted south 20 degrees west from the corresponding ground locations. The amount of shift varies from about 440 feet at a $6000-f \circ o t$ elevation to 1110 feet at a 4500-foot ground elevation.

The west edge of Warner Valley is marked by a series of prominent magnetic highs and lows that are elongated nearly parallel to the trend of the boundary escarpment. The map has been annotated to indicate which anomalies occur over the Tts geologic unit (with the letter $S$ ) and over the Tbf unit (with the letter $K$ ). The shape of the edges of the elongated anomalies are shifted in places to agree with the trend of three pairs of northwest-trending faults, but this tendency does not seem to persist into the overlying Tb to the west. The occurrence of a prominent north-elongated, magnetic low may correlate with underlying reversely magnetized rock or, possibly, may be related to a topographic effect. The letter $\underline{T}$ in a southwest-trending low to the north of Deep Creek Canyon indicates a probable 
topographic effect of the missing Tts and Tb rocks.

Several magnetic highs to the east of Warner Valley are related to outcrops of the Tb geologic unit. Three lows, denoted by the letter $\underline{R}$ are related to reversely polarized rocks of the Tb unit. The northeast and southwest edges of these northwest-trending lows appear to be fault controlled.

Warner Valley appears to coincide with a general magnetic low. Decreases in magnetic level and diversity of magnetic trends and a general increase in wavelengths are partly effects of an average 1000 to 1500-foot lower ground surface of the valley relative to the surrounding terrain. The occurrence of alluvium above Tertiary bedrock in the valley also contributes to these changes. If it is determined from other evidence that the alluvium is relatively thin, extensive hydrothermal alteration serving to destroy magnetization of the rocks beneath Warner Valley also may contribute to the reduced amplitude of the magnetic anomalies.

The magnetic contours noticeably follow the trend of the edge of the alluvium at the north edge of Warner Valley near two locations labeled with the letter $\underline{Q}$. It is unlikely that the closely-spaced northeast-trending contours northwest of the eastern of the two locations only result from terminating a large block of alluvium. The size of the gradient and persistence across an outcrop of Tertiary rock (Tb) suggest that the low mostly is the effect of a thick block of relatively non-magnetic Tertiary rock.

The letter $F$ near the center of the aeromagnetic map indicates the position of a mapped fault. The Tertiary rocks to the east are at a relatively low elevation but also would seem to have relatively low magnetization. But ground traverse w6 (Figure 8d) which is located nearby indicates rocks of relatively high magnetization. The difference of results would have to be explained by the 2300 to 2500-foot difference in observation level, the relatively small volume of rocks involved, and incompleteness of the aeromagnetic coverage.

The aeromagnetic map is dominated by a 5 by $7 \mathrm{~km}$ magnetic high near the south edge of Warner Valley (labeled P). The total amplitude of about 200 gammas is larger than anomalies in the mountains to the west, but rocks causing the latter anomalies are much closer to the flight elevation. The large high may be the magnetic effect of an intrusive stock buried below sealevel. Magnetic lows labeled $\underline{\mathrm{C}}$ and $\underline{\mathrm{D}}$ are partly the dipole effect of the large magnetic high.

\section{GRAVITY SURVEY}

The Bouguer gravity anomaly map of the crump Geyser area is dominated by a 9 by $12 \mathrm{~km}$ closed gravity low (Figure 10). The gradient along the west edge of the gravity low correlates with the fault at the west edge of Warner Valley and with a similar magnetic gradient (Figure 9). Both the northeast-trending gravity and magnetic contours curve eastward just south of Crump Geyser. The large magnetic high near the south edge of the valley is reflected as a small divergence of the gravity contour between the minus 72 and the minus 74 levels.

Gravity data were collected at station spacings of 250 to 350 feet along three east-west profiles in Warner Valley in addition to gravity stations established for regional control. The purpose of the closely-spaced stations was to provide better resolution for the location of faults, to test for changes of density within the alluvium, and to provide better control for two-dimensional interpretation. Elevations were leveled to an overall accuracy of 0.05 foot and gravity was 
observed to an accuracy of 0.05 milligal.

Profile A-A' crosses Warner Valley along the main highway (Figures 10 and 11 ) and coincides with truckborne magnetometer traverses (W1 and W5 of Figures 8 a and 8c). The gravity level is about five milligals lower on the east side of the valley compared to the west side. The gravity gradient is steeper on the west side of the valley, which would indicate that the alluvium is thicker near the west side of the valley. Only one local anomaly appears on the profile. The shape of the anomaly at point $\underline{P}$ tends to be the reverse of the shape of topography. Using a reduction density of $2.0 \mathrm{~g} / \mathrm{cm}^{3}$ for alluvium rather than the value of $2.5 \mathrm{~g} / \mathrm{cm}^{3} \mathrm{for}$ volcanic rock halves the size of the anomaly. The remaining part of the anomaly might be interpreted as the effect of being about 30 feet closer to bedrock in the topographic low. The change west of $P$ is opposite in sense to that on the magnetometer record which implies a step fault down-dropped to the east.

Profile B-B'-B" also coincides with truckborne magnetometer traverses (W8 and W9 of Figures $8 \mathrm{e}$ and $8 \mathrm{f})$, but the elevation changes are insignificant. The gravity gradient is the same as that of profile $A-A^{\prime}$ for the section from point $P$ for 1.1 $\mathrm{km}$ to the east, but is steeper than to west of point $\mathrm{P}$. A one-milligal gravity high centered $1.24 \mathrm{~km}$ west of $\mathrm{B}^{\prime}$ has about the same peak-to-trough wavelength as a corresponding magnetic change.

Profile C-C' (Figure 13) was intended to establish the gravity gradient at the west edge of Warner Valley near a location about as far north of Crump Geyser as BB'-B" is to the south. The gradient is smaller than at either of the other surveyed profiles, indicating that the major fault is located farther to the west of the edge of the alluvium or the throw is less.

Two-dimensional interpretation of the configuration of the valley floor beneath the alluvium is most accurate if a profile is chosen at right angles to the strike of the anomaly. None of the surveyed profiles meet this criterion. Therefore, an arbitrary profile, D-D' (Figure 14), was selected that passes nearly through the center of the gravity low, which corresponds to the location of the greatest thickness of alluvium.

One would assume from the asymmetric appearance of the gravity map (Figure. 10) and the gravity profiles (Figures 11, 12, and 14) that the thickest part of the alluvium occurs near the west side of Warner Valley. But if the gravity low is wholly attributed to the contrast in density between the alluvium and the surrounding Tertiary rocks, one must assume the existence of a regional gravity anomaly that coincides with the observed profile west of the west side of the valley and rejoins the observed anomaly at a 13-milligal lower level near the east edge of the valley where Tertiary rocks crop out. Consequently the residual anomaly and the computed depth profile would be shaped fairly symmetrically (Figure 14). A maximum alluvium thickness of about 2700 feet (base about 1800 feet above sea level) can be derived from the residual gravity anomaly, if the average density of the alluvium is $2.0 \mathrm{~g} / \mathrm{cm}^{3}$ compared to $2.5 \mathrm{~g} / \mathrm{cm}^{3}$ for the underlying Tertiary rocks.

The shape of the regional anomaly indicates that the fault zone near the west edge of Warner Valley and south of Crump Geyser separates two units of rock beneath the alluvium, in which the less dense unit is located to the east of the fault. The relative flatness of the observed anomaly to the west of Warner Valley indicates that the transition between the two units occurs over a fairly short distance interval. The gravity survey should be carried to the east of the east edge of Coleman Valley to determine the location of the east edge of the down- 
dropped block of low density rock. Here the contact between the Tts and Tb rock units is located at a comparable elevation (about 6000 feet) to the location of the contact just west of Warner Valley.

If a greater part of the observed gravity anomaly is attributed to the contrast in density between the underlying rocks, the alluvium would be correspondingly thinner than illustrated in Figure 14. The audio-magnetotelluric survey was not carried far enough south to evaluate the geothermal potential near the gravity low. As stated in an earlier section of the report, the truckborne magnetic data show very few locations where estimates of the maximum depth to the base of the alluvium can be applied. The rock underlying the alluvium has a lower density than the surrounding basement rocks and has a relatively low intensity of magnetization. 


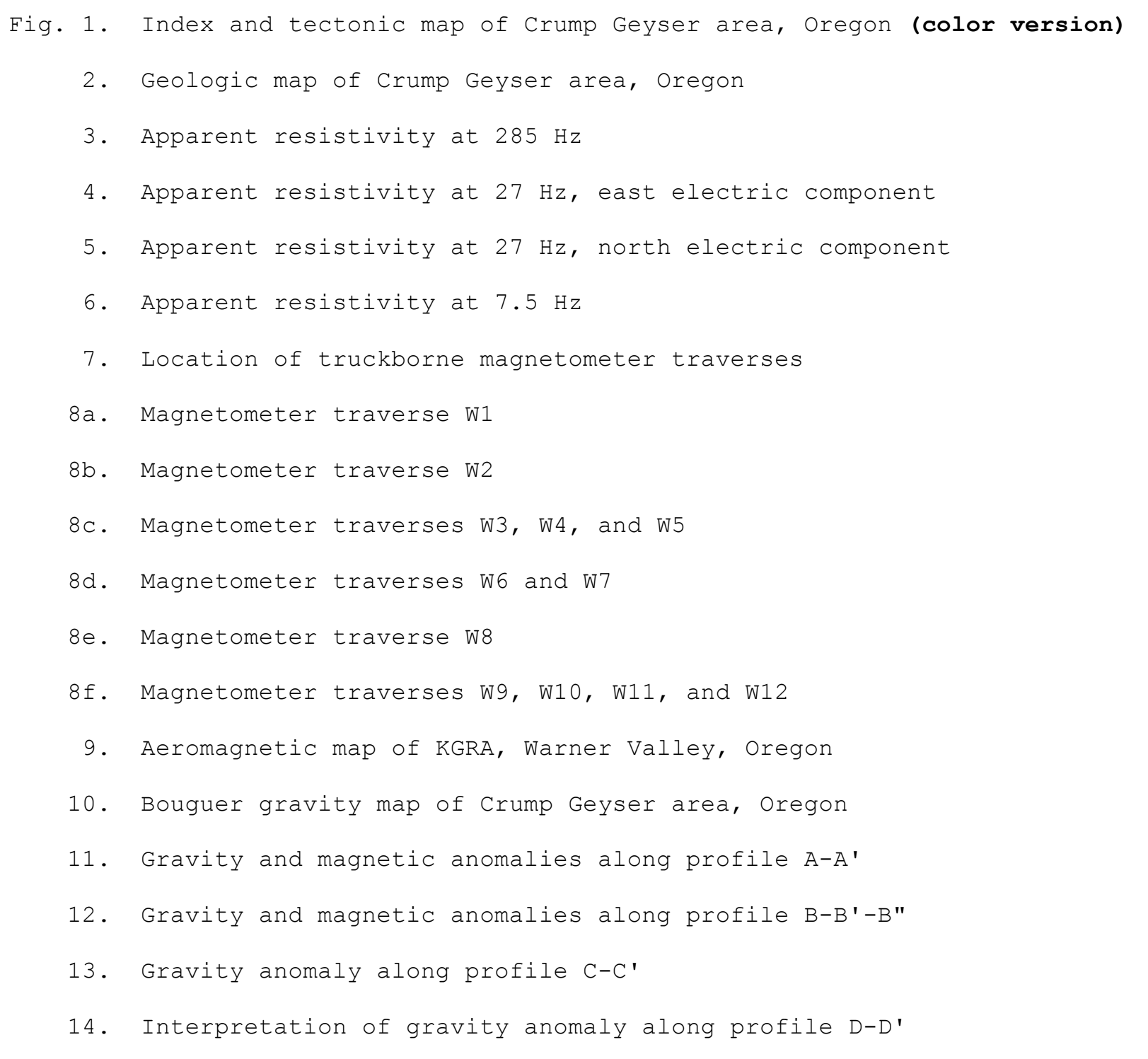




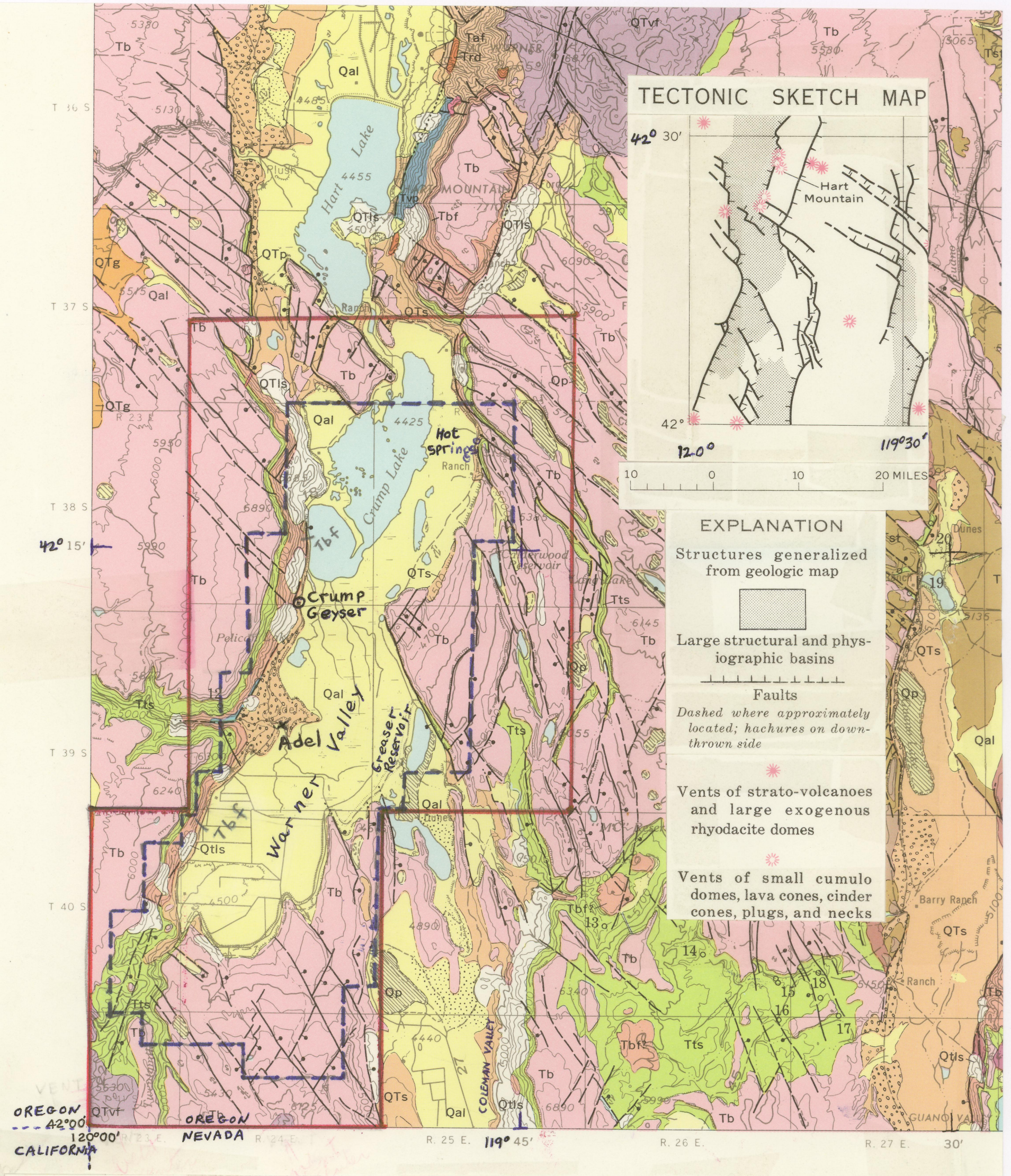

Fig. 1. Index and tectonic map of Crump Geyser area, Oregon 


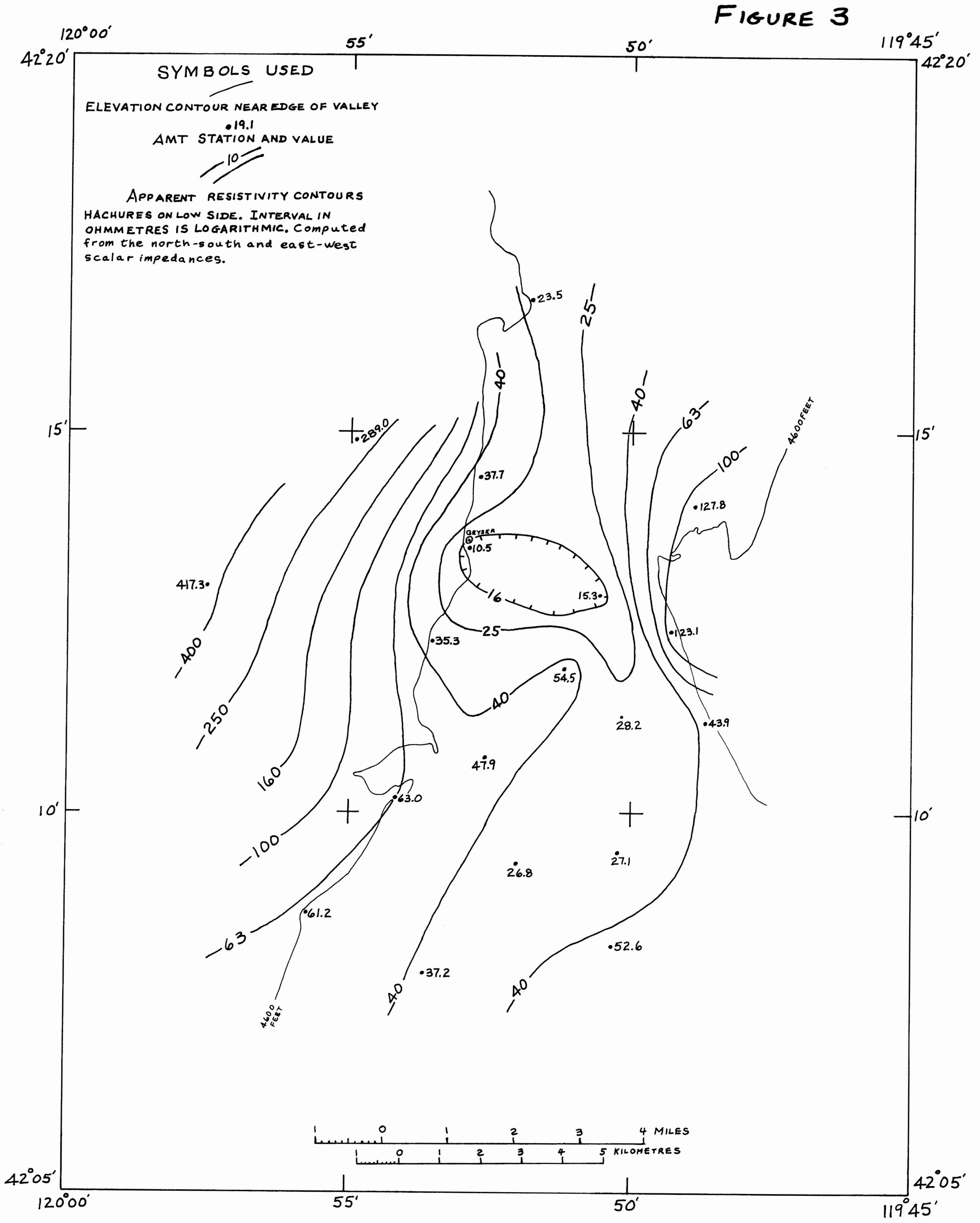

fig. 3. Apparent resistivity at $285 \mathrm{~Hz}$. 


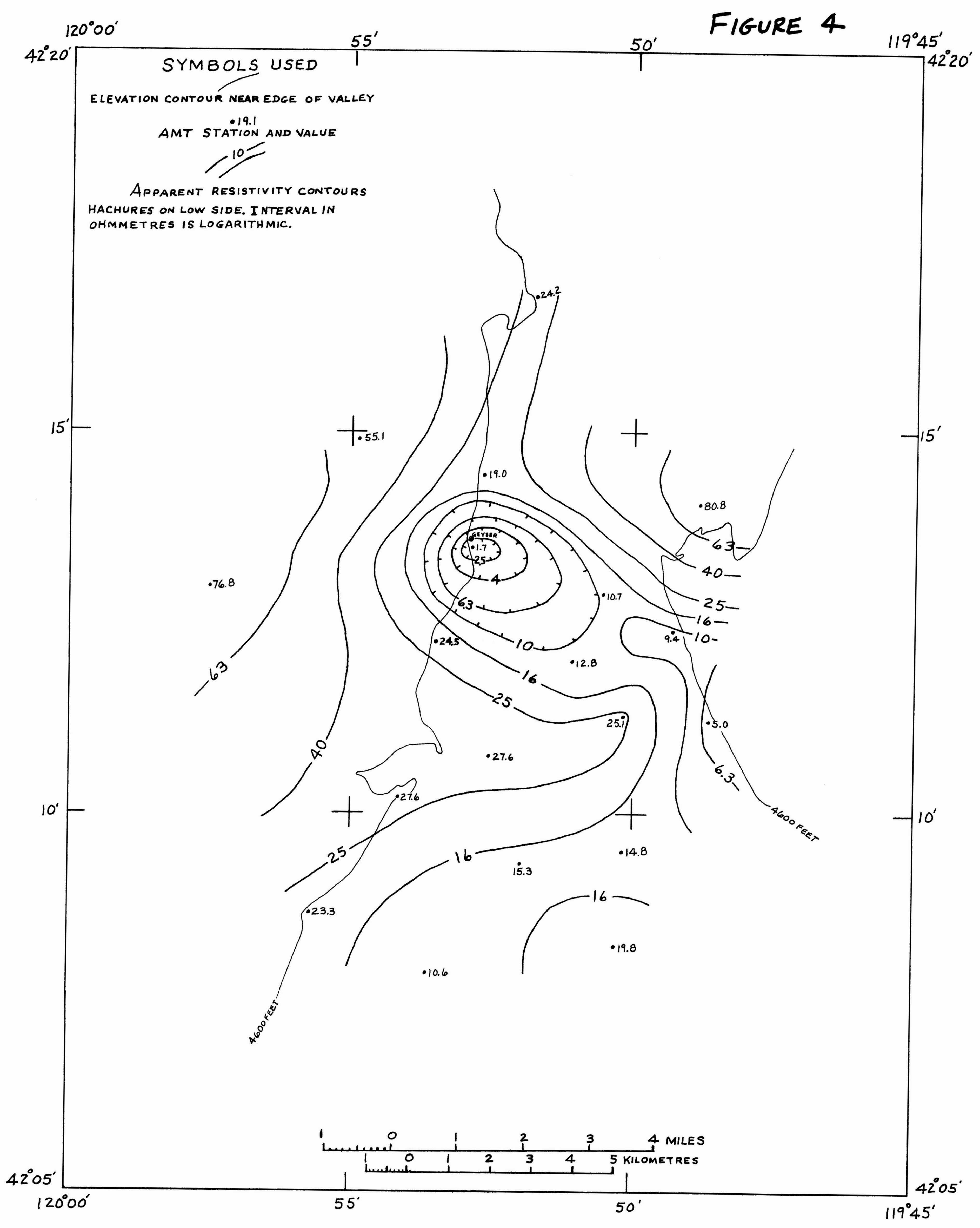

Fig. 4. Apparent Resistivity at $27 \mathrm{~Hz}$., east electric component. 


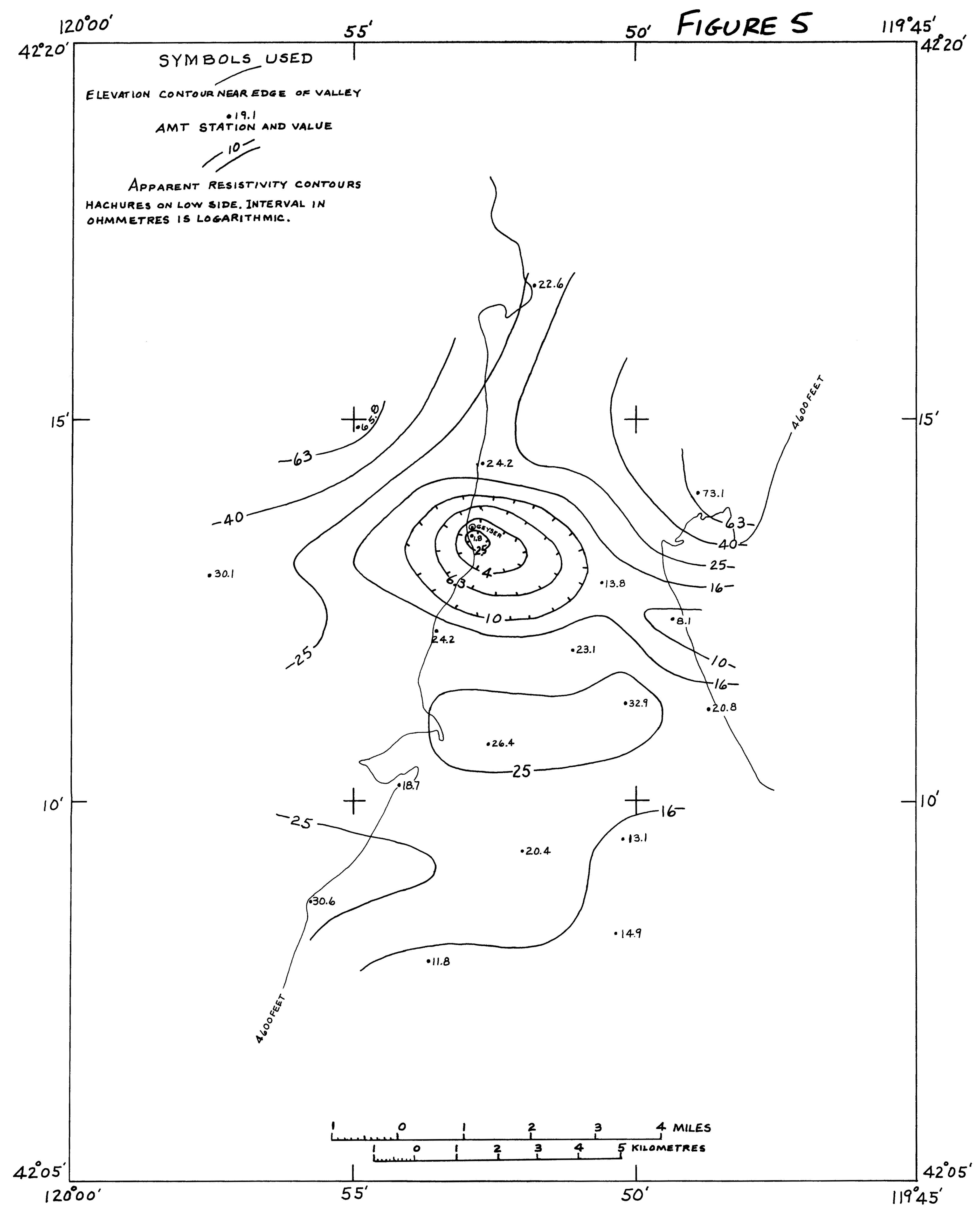

Fig. 5. Apparent resistivity at $27 \mathrm{~Hz}$, north electric component. 


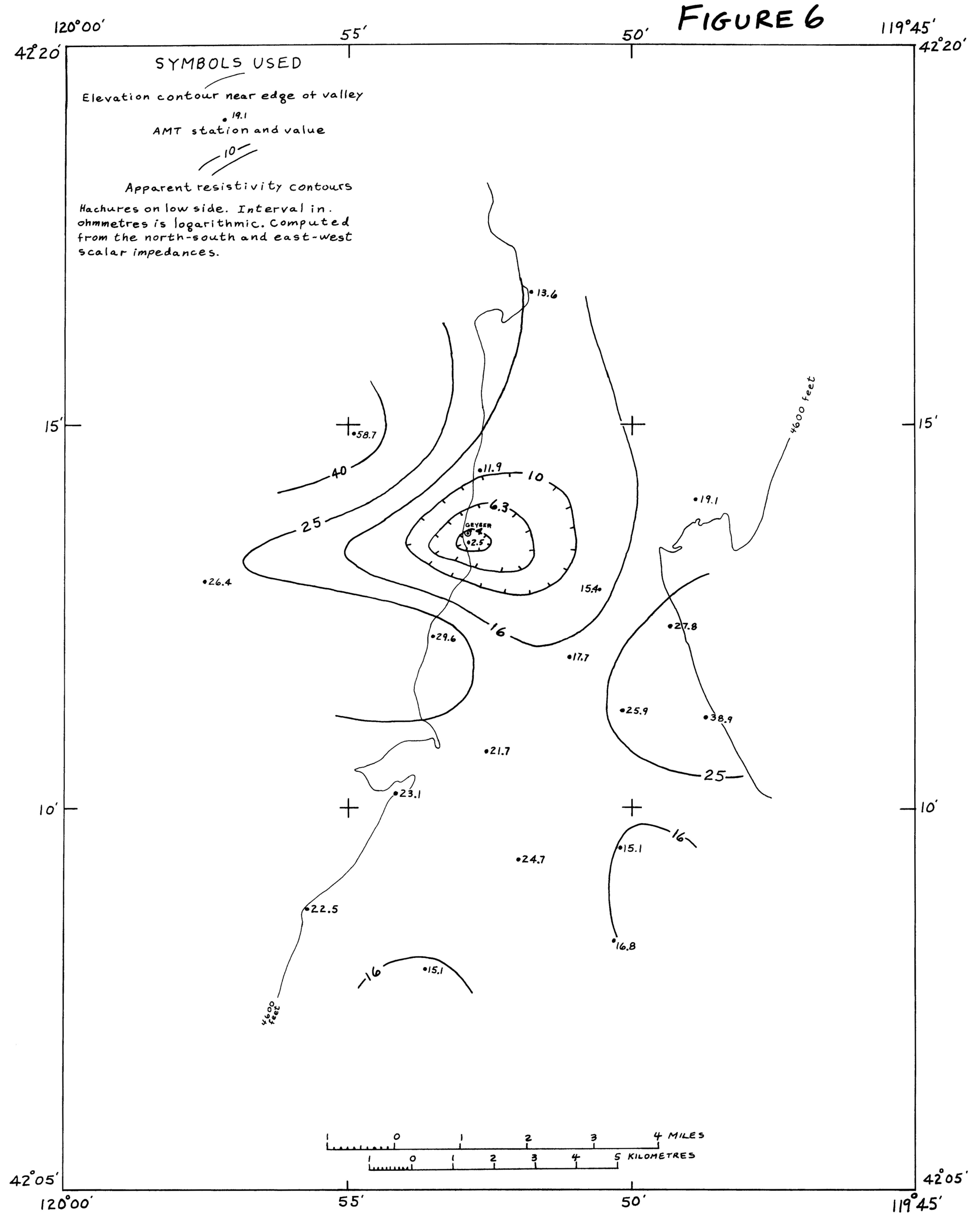

FIG. 6. APPARENT RESISTIVITY AT $7.5 \mathrm{~Hz}$. 


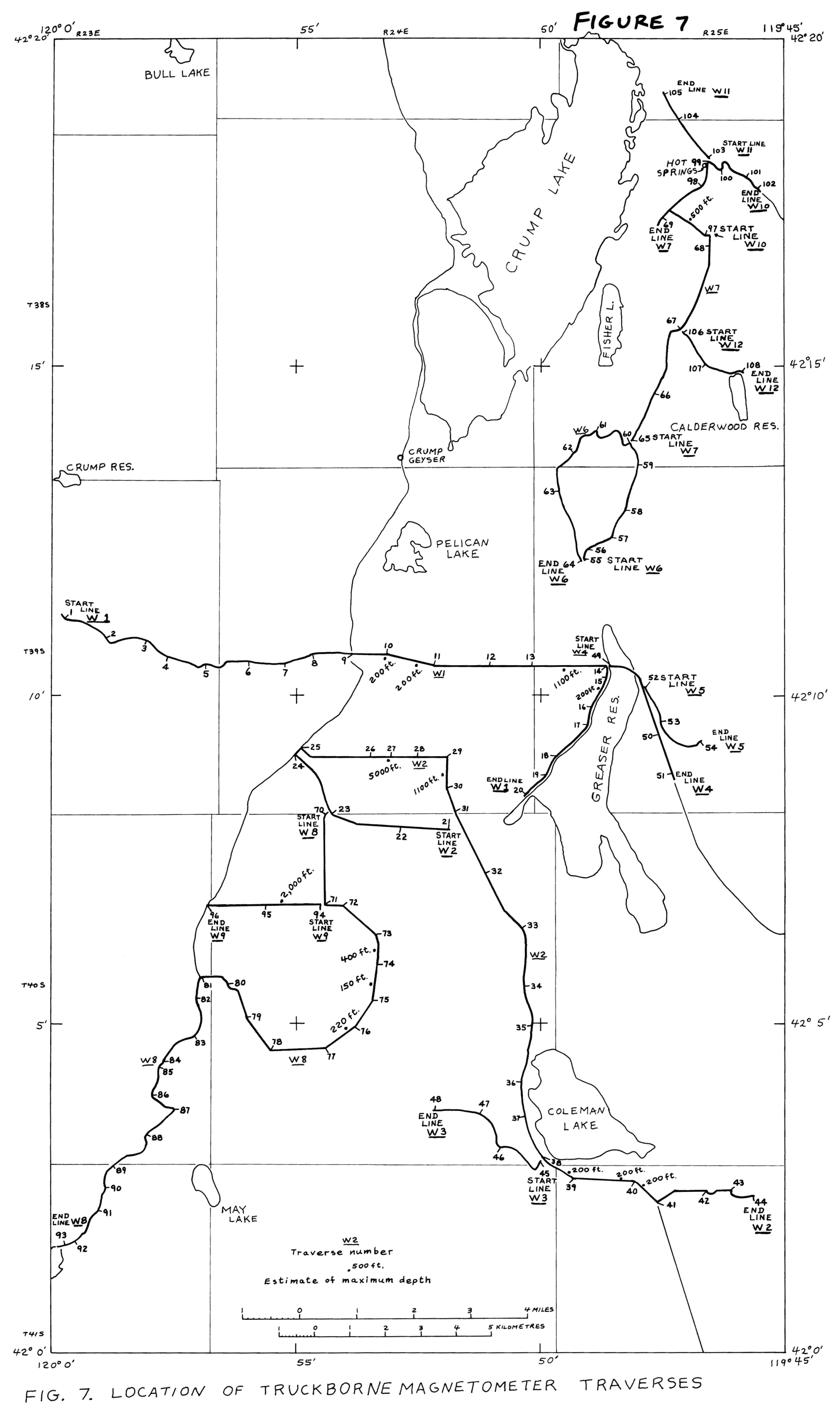


WI

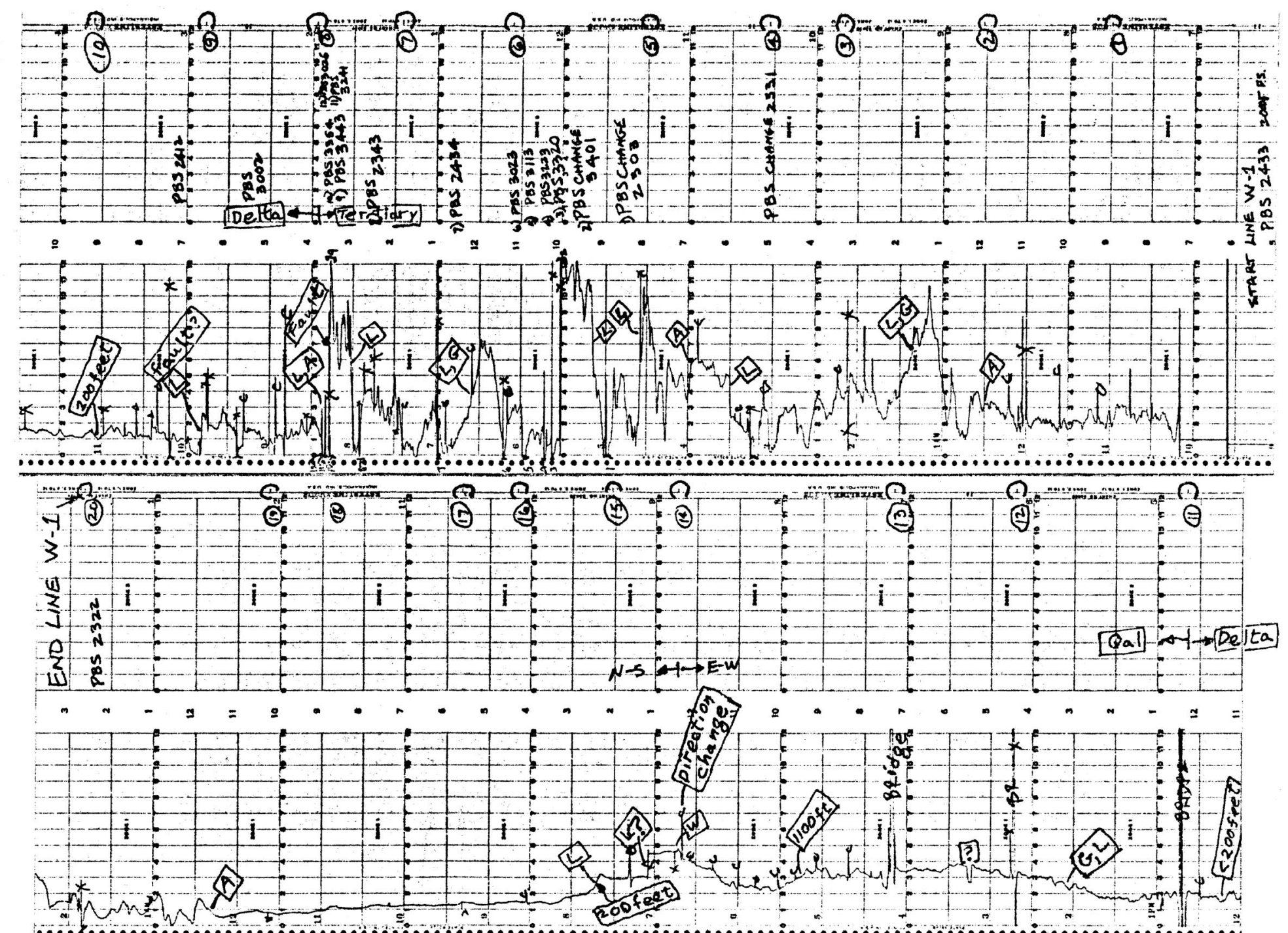

WI

Fig。 8a. Magnetometer traverse W1 

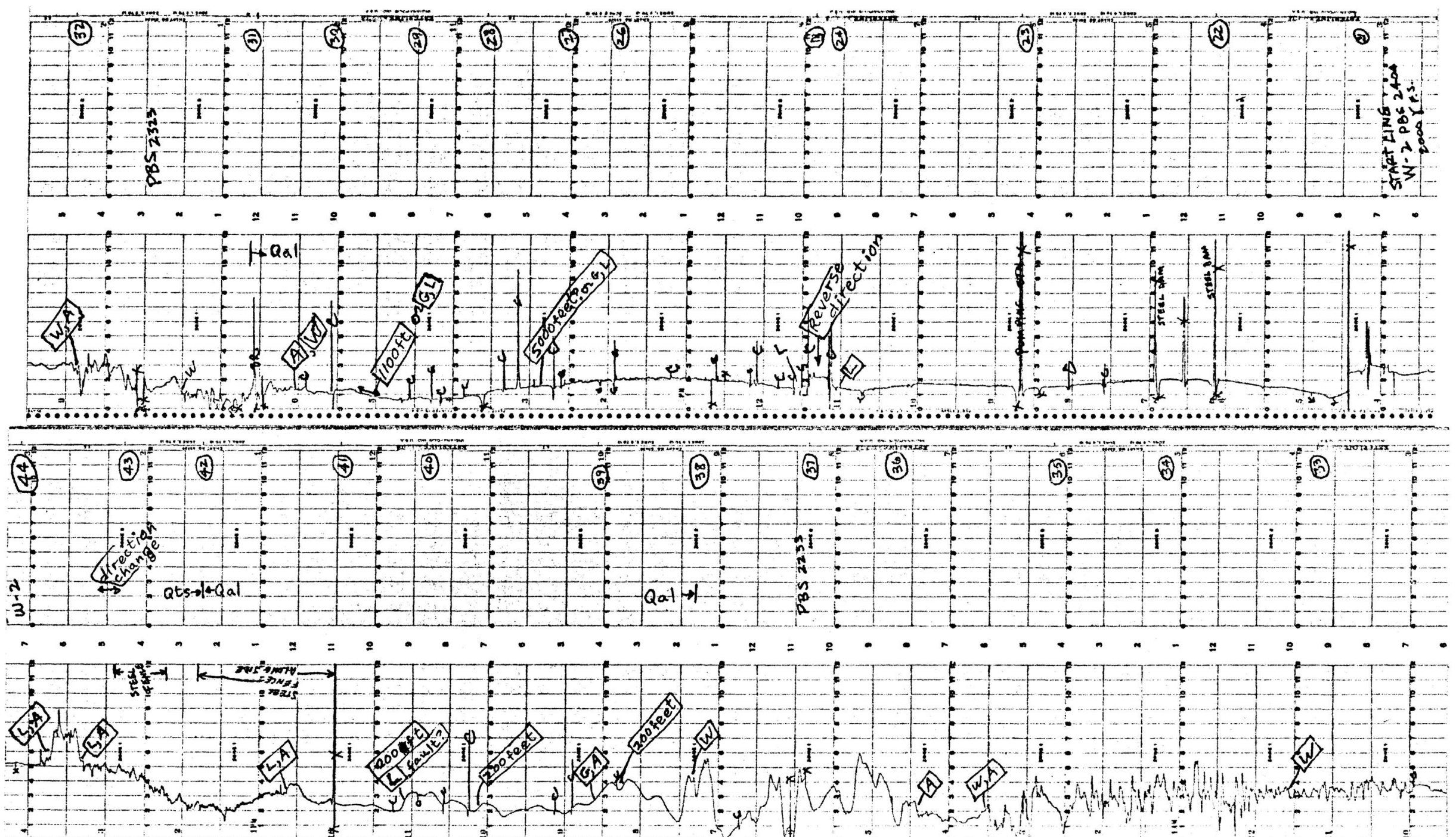

Fig. 8b. Magnetometer traverse W2 

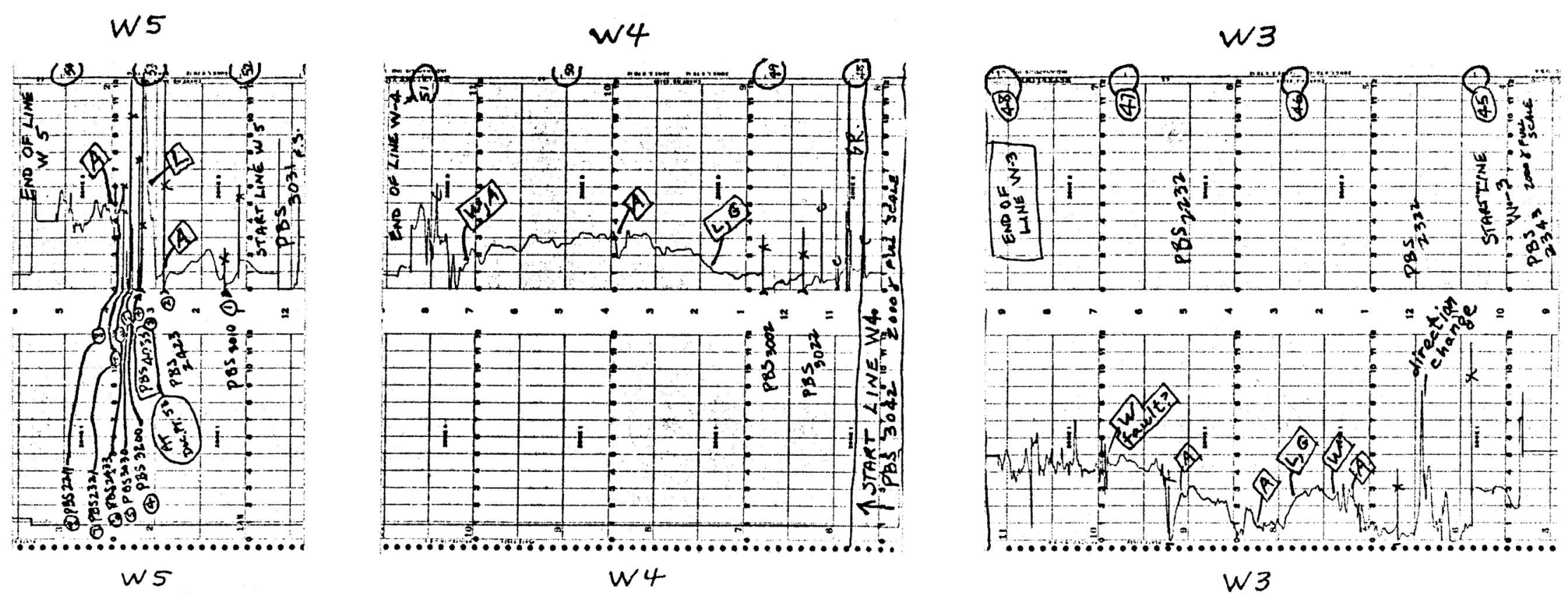

Fig. 8c. Magnetometer traverses W3, W4, and W5 


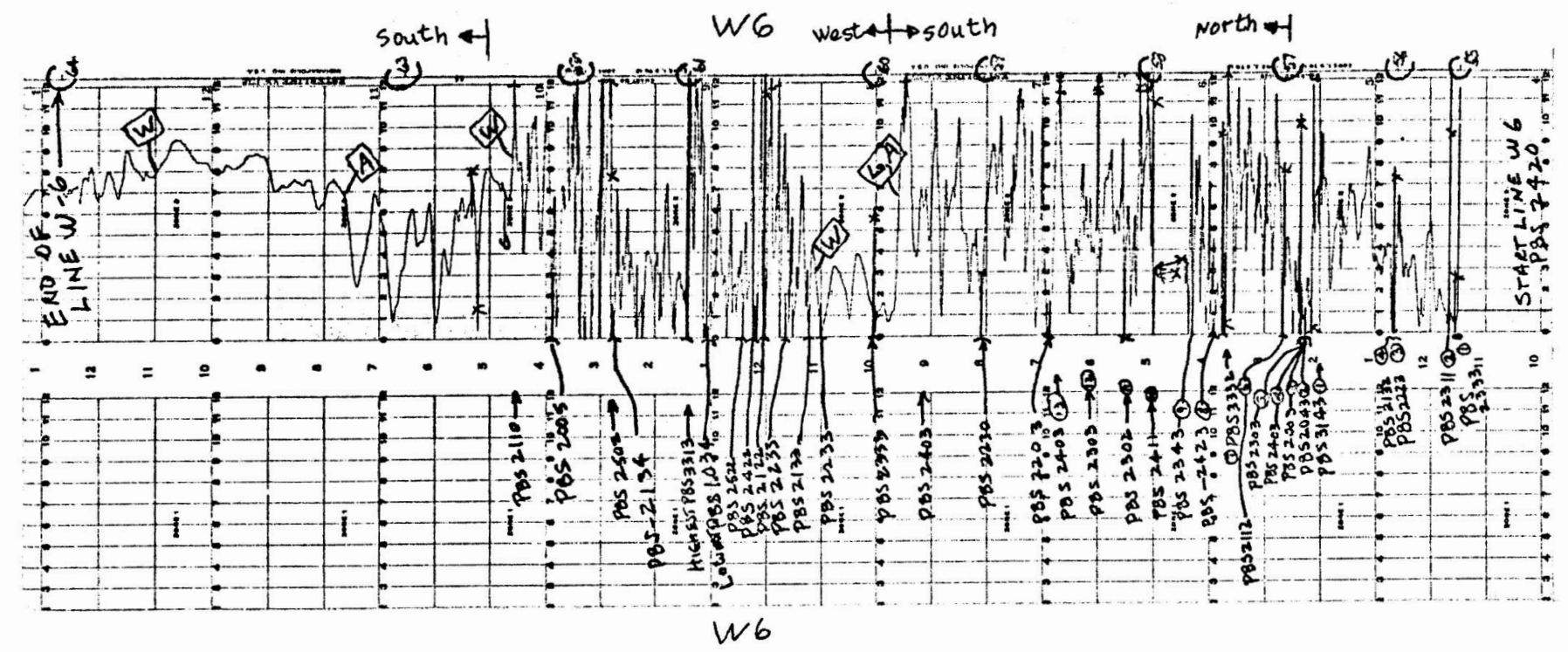

W7

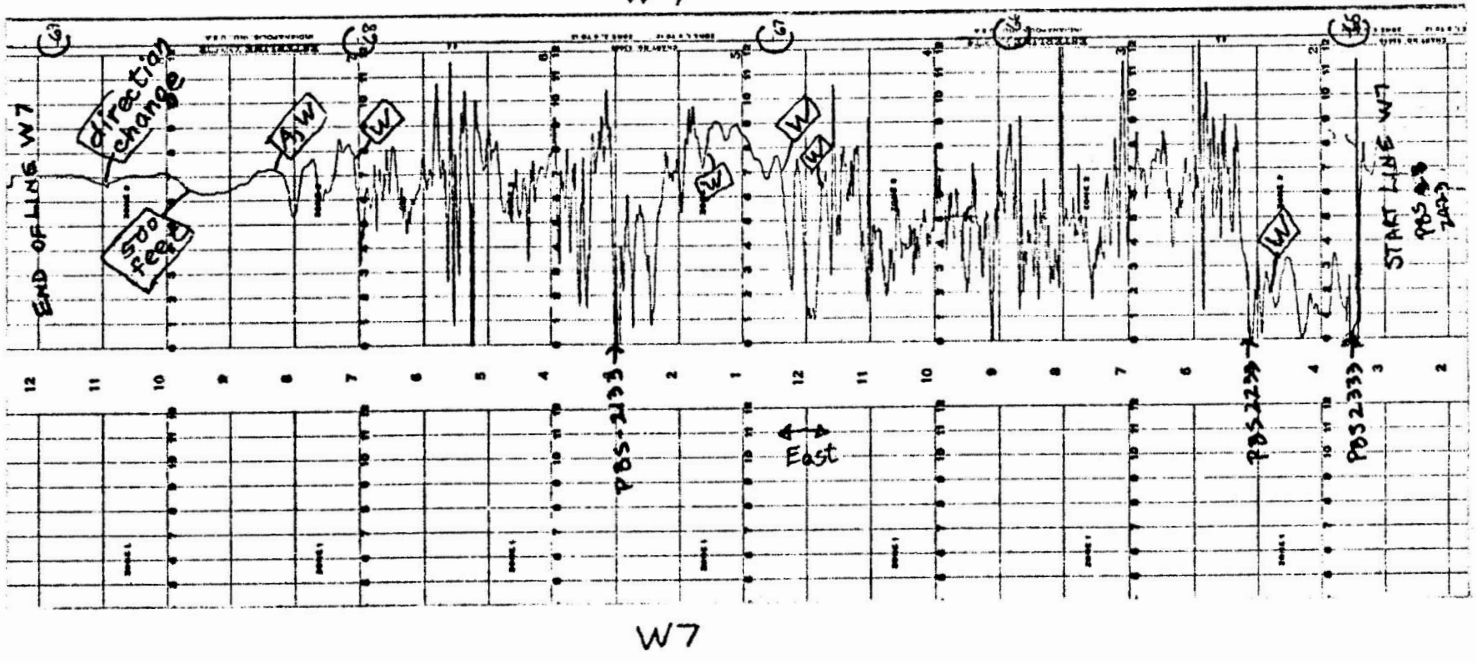

Fig. 8d. Magnetometer traverses $W 6$ and W7 


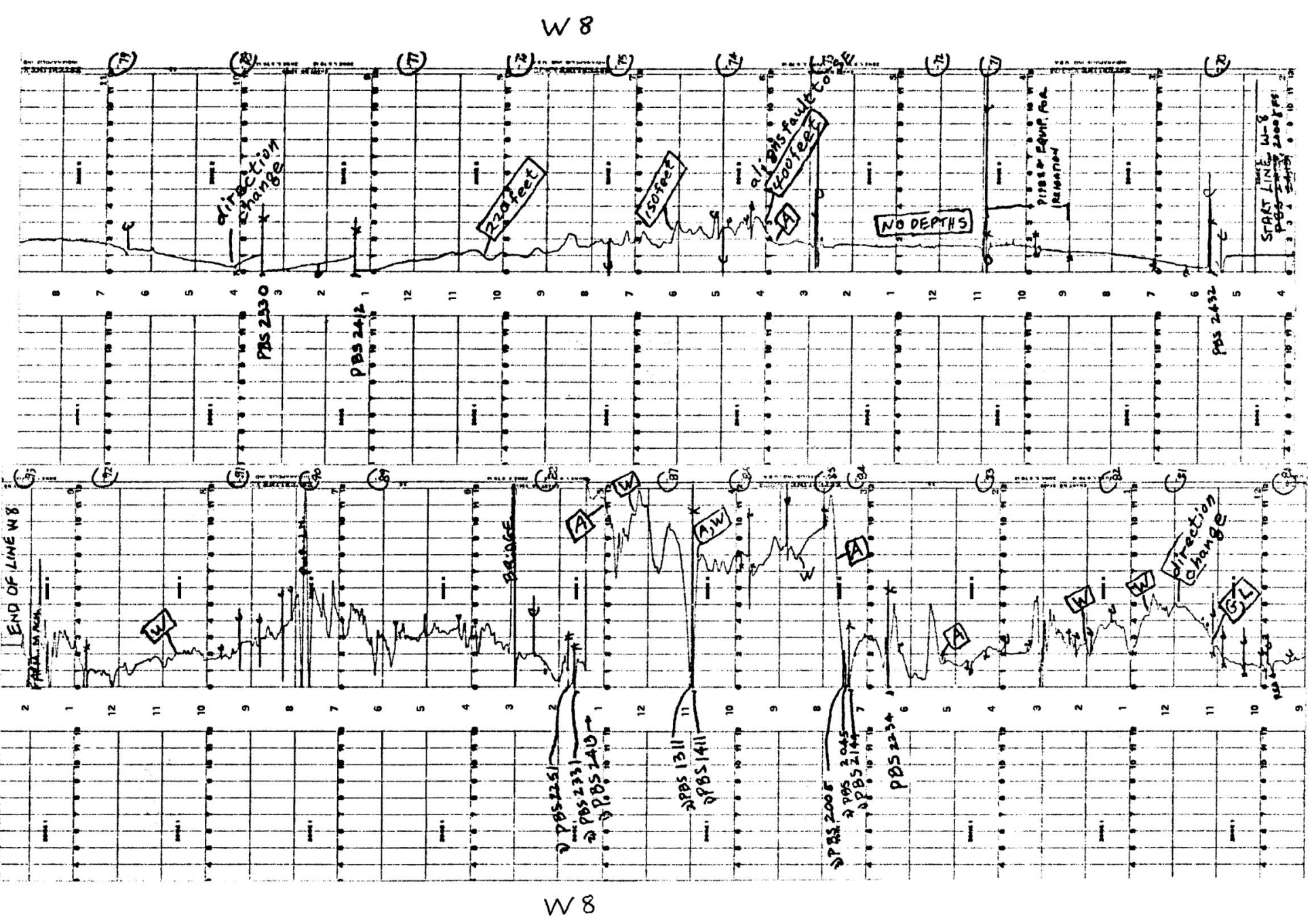

Fig. 8e. Magnetometer traverse W8 


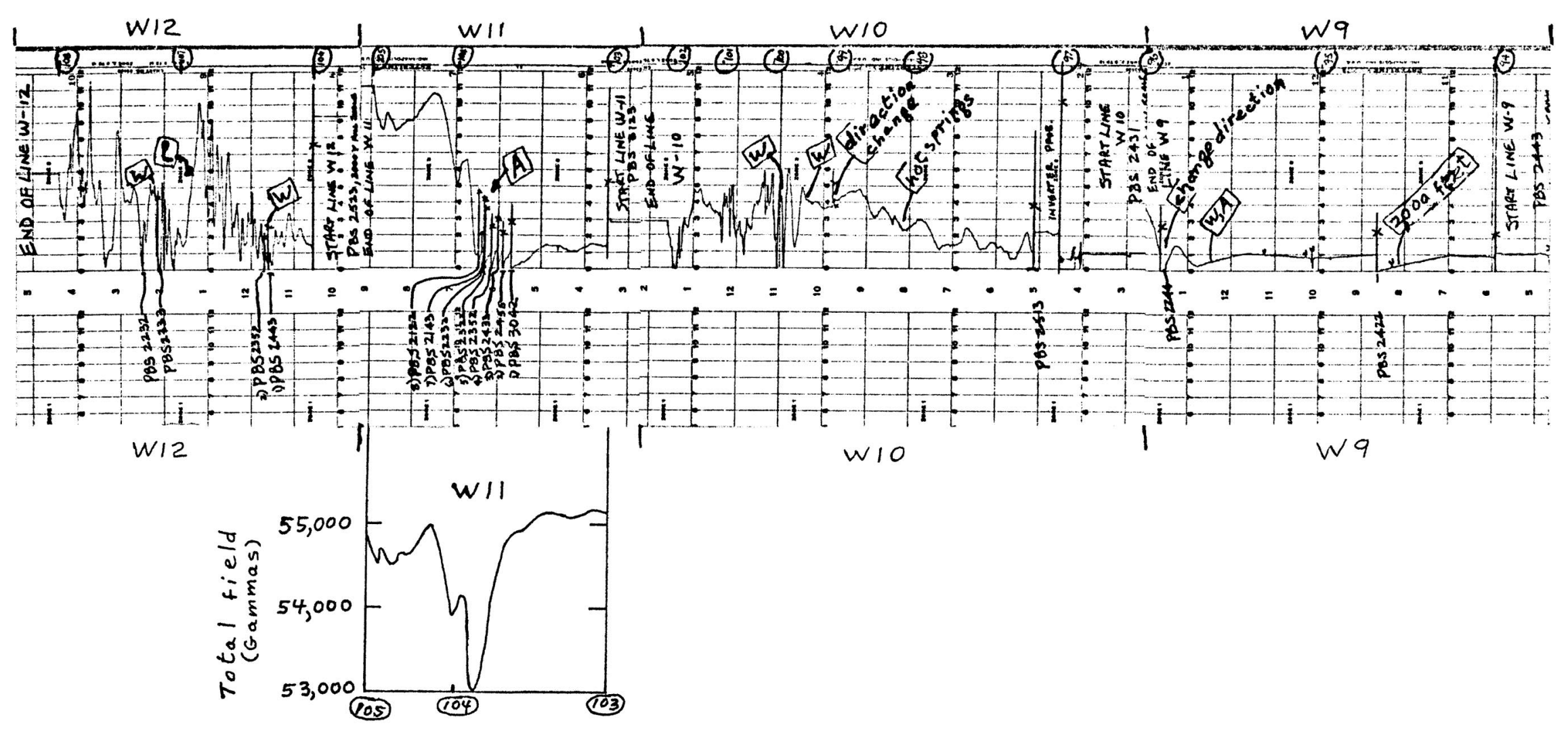

Fig. 8f. Magnetometer traverses W9, W10, W11, and W12 


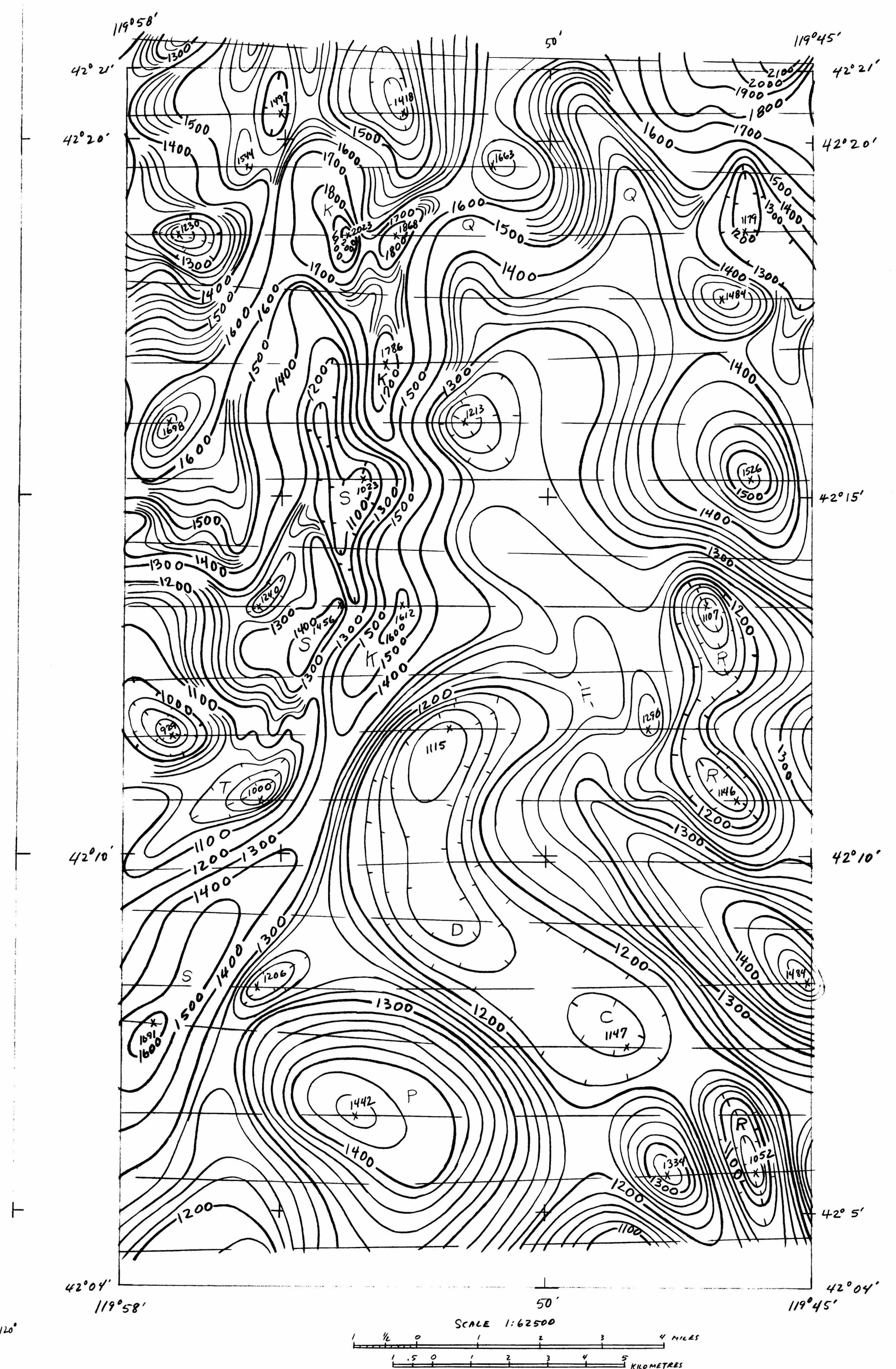

Fig. 9 Aeromagnetic Map Or KGRA Prosect $\# 2011$

Warner Valley oregon 1975

FlOWN AT 7000' BAROMETRIC

CONTOUR InTERUAL 20:100 GAMMAS 


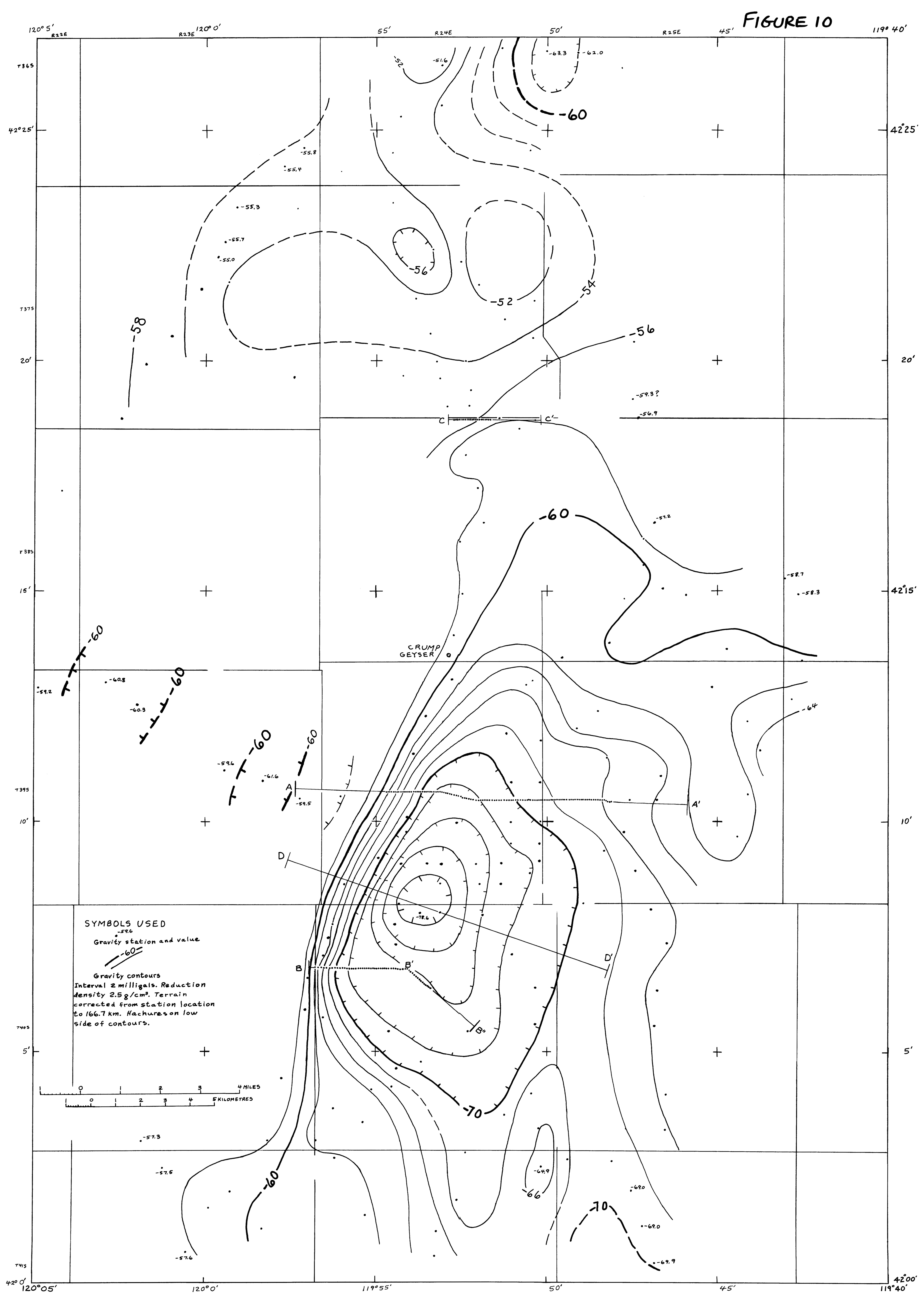


Total magnetic field

$A^{\prime}$
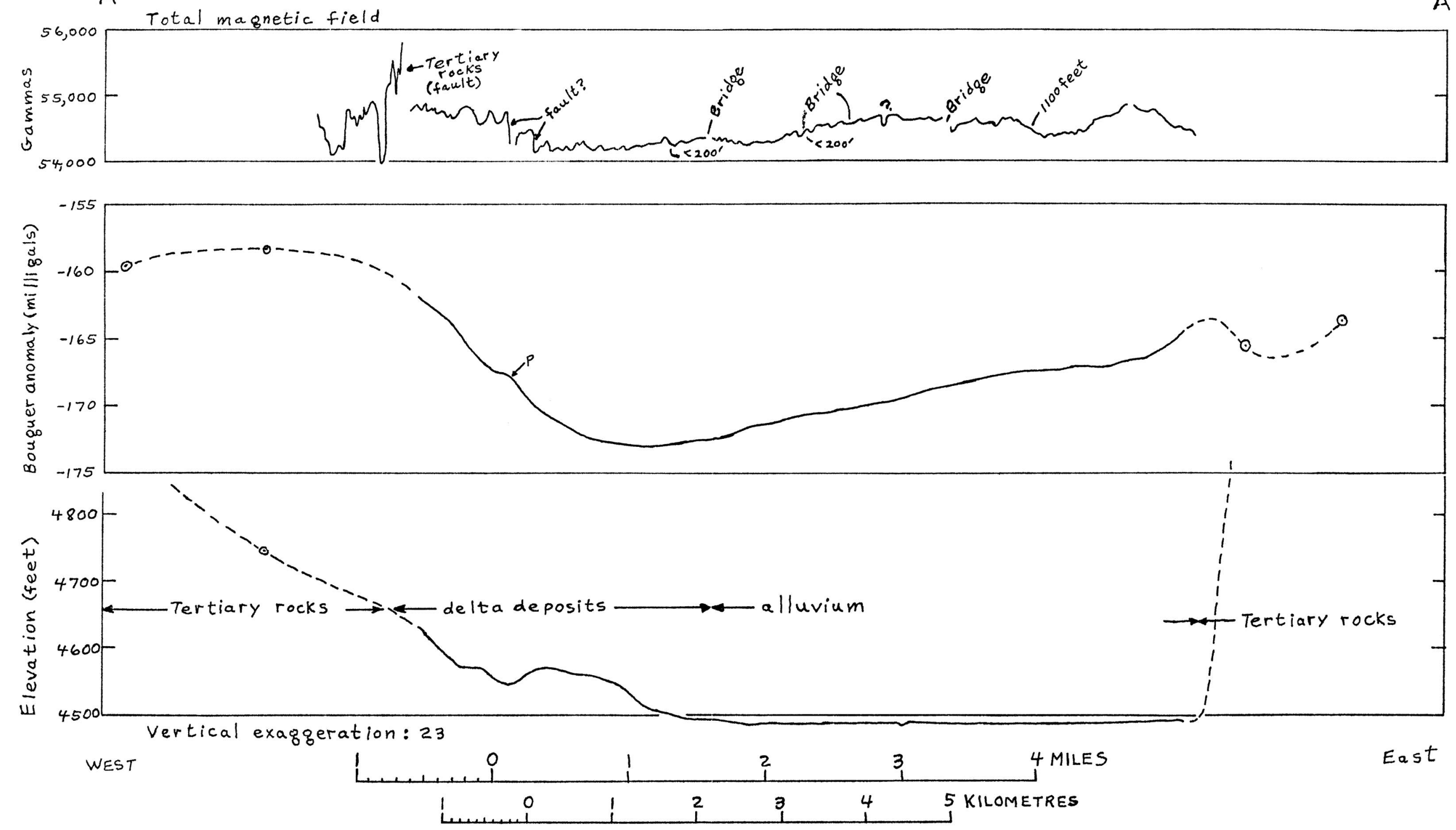

Fig. 11. Gravity and magnetic anomalies along profile A-A' 


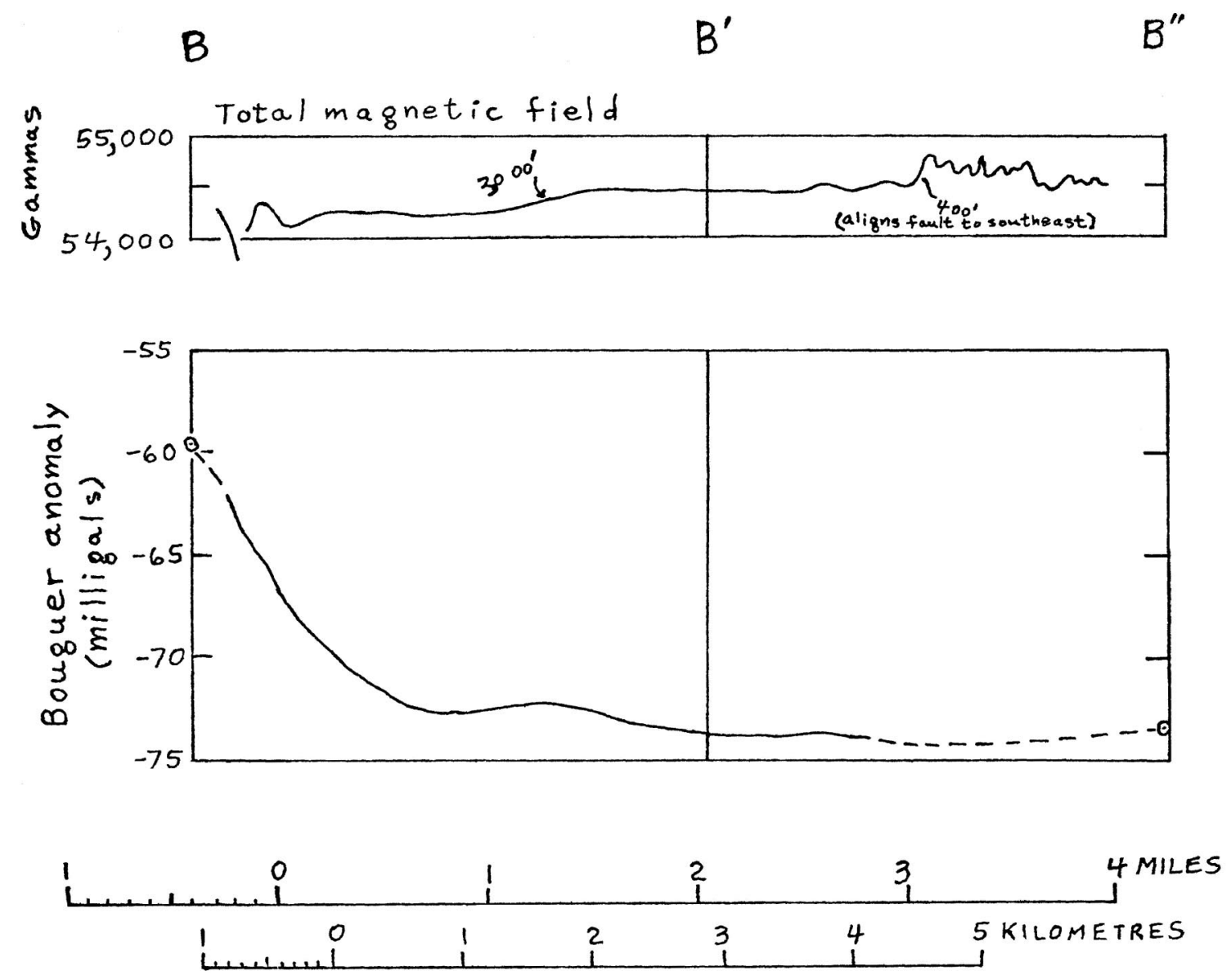

Fig. 12. Gravity and magnetic anomalies along profile $B-B^{\prime}-B^{\prime \prime}$ 

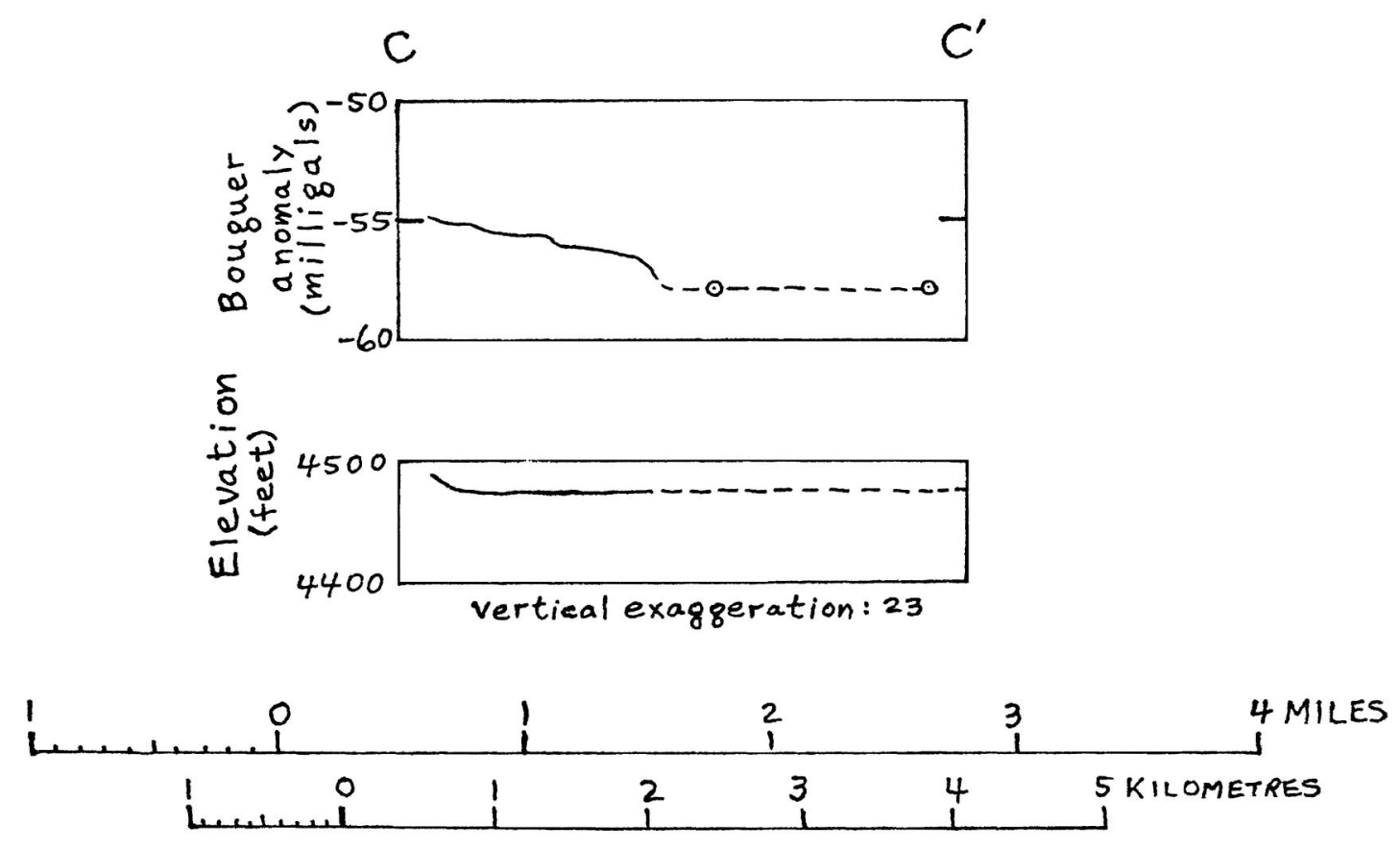

Fig. 13. Gravity anomaly along profile C-C' 

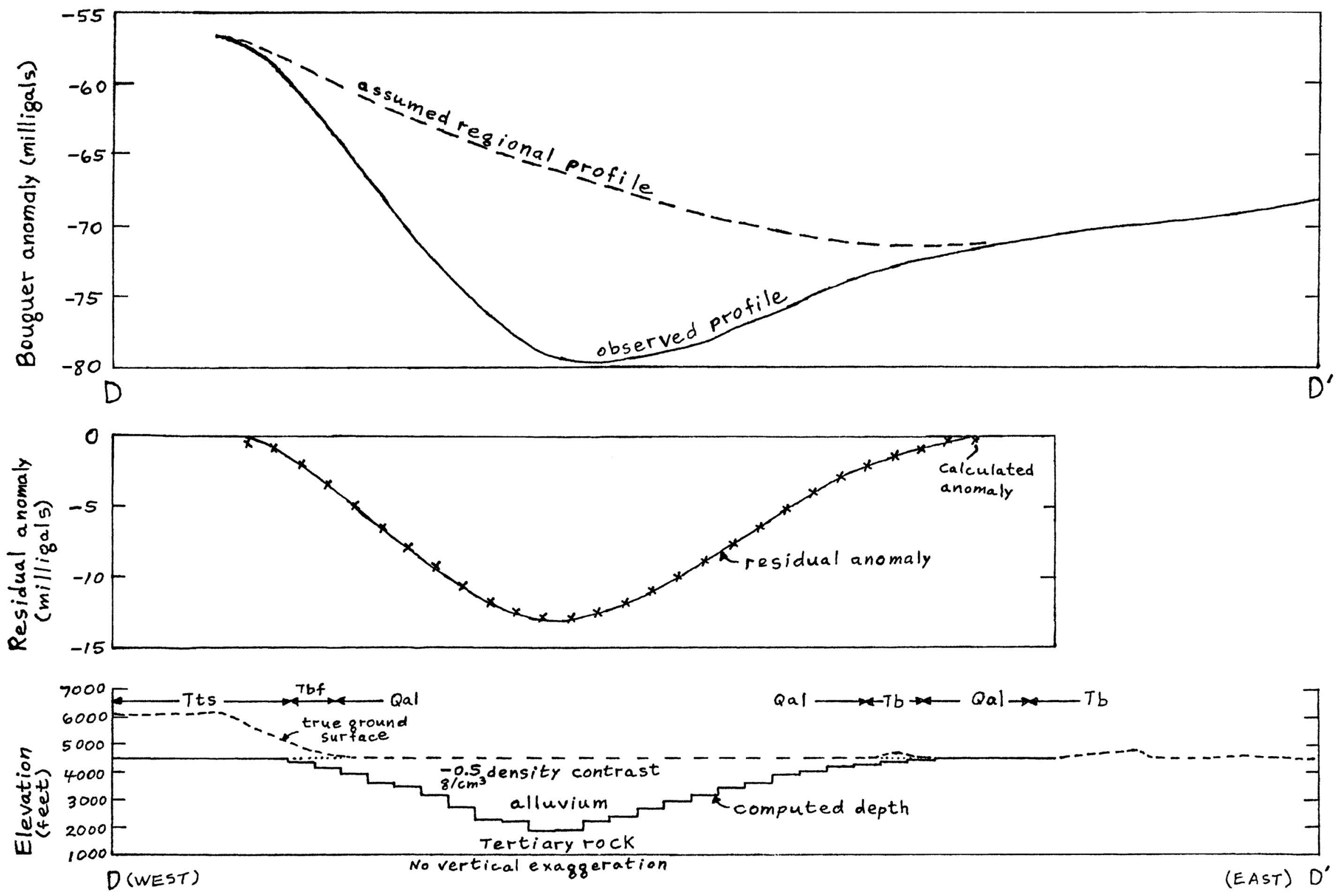

Fig. 14. Interpretation of gravity anomaly along profile $D-D^{\prime}$ 


\title{
APPENDIX 2-REPRINT OF NTIS PUBLICATION PB-245-426/AS
}

\author{
Gravity data in crump Geyser area, Oregon \\ by \\ Donald Plouff \\ U. S. Geological Survey \\ Menlo Park, California
}

This report is preliminary and has

not been edited or reviewed for

conformity with Geological survey

standards and nomenclature. 
DESCRIPTION OF GRAVITY SURVEY

Gravity readings were taken with LaCoste-Romberg Meter G17B at 162 locations to obtain a Bouguer gravity anomaly map of the Crump Geyser area (Plouff and Conradi, 1975, pl. 9). Gravity readings also were taken at 194 locations at intervals of 70 to 120 meters along three traverses ( $A-A^{\prime}, B^{\prime} B^{\prime}$, and $C_{-} C^{\prime}$ on figure 1) to supplement the regional gravity survey and to provide better resolution for interpretation of near-surface gravity anomalies (Plouff and Conradi, 1975, pls. 10-12). The gravity survey is located in an area of geothermal resource potential in south central Oregon (fig. 1).

\section{ACCURACY OF SURVEYED ELEVATIONS}

The elevation control along the three traverses was carried to the nearest 0.01 foot by using standard spirit leveling techniques. This quality of elevation control made possible the determination that the elevation of a U.S. Geological Survey benchmark on a bridge over Deep Creek (1.5 mile east of Adel) has decreased $0.24 \pm 0.02$ foot since 1965 relative to benchmarks at distances of 0.4 and 0.6 miles on either side. Ties between benchmarks along traverse $A-A^{\prime}$ indicates the surveyed elevations probably are accurate to better than 0.05 foot. The absolute elevation accuracy along traverse C-C' is not as good as along the other two traverses because a tie was made to a spot elevation and a lake-level elevation rather than to a benchmark. The relative accuracy along the surveyed profiles, however, is significantly greater than the 0.2-foot accuracy needed for consistency with the maximum reading accuracy of 0.01 milligal for Gravity Meter G17B. 
OBSERVED GRAVITY

Absolute values of observed gravity were established by tying the gravity readings to a primary base in Menlo Park, California (station 173), which is incorporated in a network of base stations located throughout California (Chapman, 1966, p. 36). Gravity readings also were taken at three secondary bases of the California network and at a station in Klamath Falls, Oregon, of the world relative gravity reference network (Jablonski, 1974). A correction of 0.81 milligal was added to the observed gravity value at Klamath Falls (Courthouse station ACIC 1300-2 or IGB 15721B) to account for a nearly constant difference between gravity values of the two networks (written communication, H.W. Oliver, 1975). The overall tide-corrected drift curve indicates that the value determined for the base at Adel, Oregon is tied to the station at Klamath Falls within an accuracy of about 0.05 milligal and is tied to the base at Menlo Park within an accuracy of about 0.08 milligal (fig. 2). Sudden local departures on the drift curve indicate that observed gravity errors of 0.1 milligal could occur at non-repeated gravity stations.

The observed gravity values at all stations in the Crump Geyser area were tied to a local base at Adel, Oregon. The base reading was taken on a small concrete slab that encloses the waste disposal trap at trailer site number 5, located about 100 feet to the west of the Adel store and post office. The gravity value there is 979,924.20 \pm 0.08 milligals, as tied to the California base network datum. Another base station was established in case the above-described site is destroyed or is inaccessible. This station is located at the northwest corner of a 3-by 7-foot concrete slab to the north of the west door (to Post Office section) of the Adel store and is located 
about 30 feet west southwest of the gas pumps. The gravity value there is $979,923.75$ milligals, according to a gravity difference of $0.45 \pm 0.02$ milligal relative to the trailer site base. The locations of both base stations are at $42^{\circ} 10.59^{\prime}$ north latitude and $119^{\circ} 53.87^{\prime}$ west longitude and the elevations are about 4535 and 4538 feet above sea level, respectively.

\section{GRAVITY ANOMALIES}

Principal facts, free-air anomalies, and complete Bouguer anomalies for all the gravity stations established by the U.S. Geological Survey (fig. 1 and Plouff and Conradi, 1975, pl. 9) in the Crump Geyser area are listed in this report (table 1). The prefix, W, for station names is used for regional control stations and the prefixes WA, WB, and WC refer to stations located along the three closely-spaced traverses. The four-digit code associated with each gravity station can be used to describe the location (table 2), estimate the elevation accuracy (table 3), estimate the accuracy of horizontal location (table 4), and to estimate the accuracy of the observed gravity (table 5).

Free-air gravity anomalies (table 1) were determined by using the International Gravity Formula of 1930 for the normal gravity on the ellipsoid and Swick's (1942, p. 65) formula for the free-air correction. Bouguer, curvature, and terrain corrections were added to the free-air anomaly at each station to determine complete Bouguer anomalies at reduction densities of 2.50 and $2.67 \mathrm{~g} / \mathrm{cm}^{3}$. Hand terrain corrections, using conventional cylindrical compartments, were estimated in the distance interval from the station location to $0.9 \mathrm{~km}(2,936$ feet). The terrain correction in the remaining 


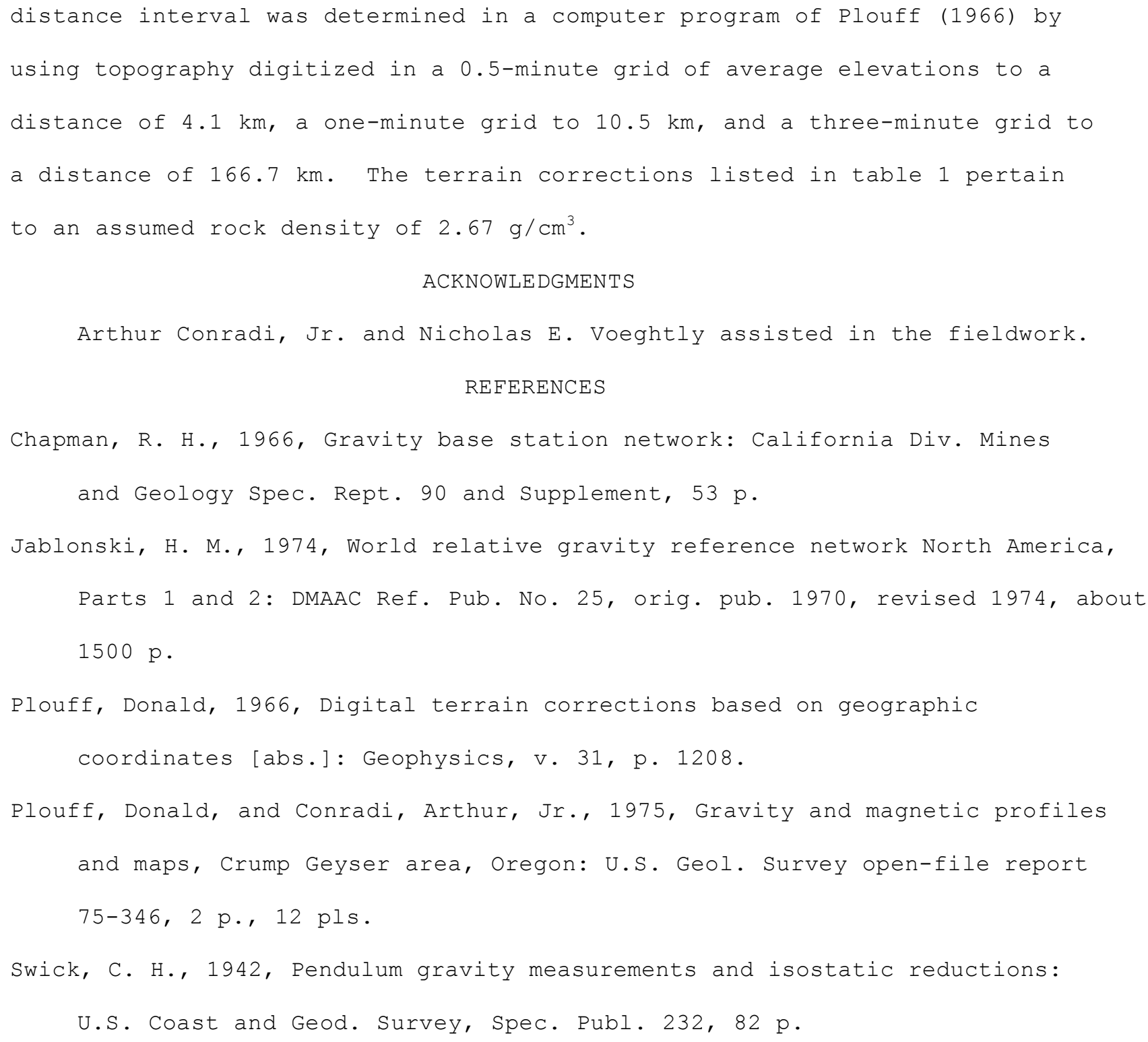


TABLE 1. PRINCIPAL FACTS AND GRAVITY ANOMALIES, CRUMP GEYSER AREA, OREGON.

\begin{tabular}{|c|c|c|c|c|c|c|c|c|c|c|c|c|c|}
\hline & & & & & & & & OBSERVED & FREE AIR & TERP & $I N$ & BOUGUER & ANOMALY \\
\hline STA & $\mathrm{ION}$ & $\mathrm{CODE}$ & $\mathrm{LAT}$ & TUDE & $\mathrm{LONGI}$ & TUDE & ELEVATION & GRAVITY & ANOMALY & HAND & TOTAL & 2.67 & 2.50 \\
\hline & & & DEG & MIN & $\mathrm{DEG}$ & MIN & FEET & MGAL & MGAL & MG & & MG & \\
\hline $\mathrm{W}$ & 1 & G534 & 42 & 9.99 & 119 & 50.19 & 4485.0 & 979926.40 & -25.97 & 0.01 & 0.81 & -179.47 & -169.70 \\
\hline $\mathrm{W}$ & 2 & F534 & 42 & 9.52 & 119 & 50.19 & 4486.0 & 979924.25 & -27.32 & 0.01 & 0.77 & -180.89 & -171.11 \\
\hline $\mathrm{W}$ & 3 & F534 & 42 & 9.13 & 119 & 50.19 & 4486.0 & 979922.89 & -28.10 & 0.01 & 0.74 & -181.70 & -171.92 \\
\hline$W$ & 4 & G534 & 42 & 8.87 & 119 & 50.48 & 4488.0 & 979922.26 & -28.15 & 0.01 & 0.73 & -181.84 & -172.05 \\
\hline $\mathrm{W}$ & 5 & G534 & 42 & 8.64 & 119 & 51.33 & 4487.0 & 979921.35 & -28.82 & 0.01 & 0.73 & -182.46 & -172.68 \\
\hline $\mathrm{W}$ & 6 & F534 & 42 & 9.09 & 119 & 51.31 & 4486.0 & 979921.72 & -29.21 & 0.01 & 0.77 & -182.78 & -173.01 \\
\hline$W$ & 7 & G534 & 42 & 9.52 & 119 & 51.03 & 4487.0 & 979923.39 & -28.09 & 0.01 & 0.78 & -181.68 & -171.91 \\
\hline$W$ & 8 & G534 & 42 & 9.98 & 119 & 51.02 & 4486.0 & 979924.30 & -27.96 & 0.01 & 0.83 & -181.47 & -171.70 \\
\hline $\mathrm{W}$ & 10 & F534 & 42 & 12.00 & 119 & 49.12 & 4491.0 & 979934.70 & -20.12 & 0.32 & 1.53 & -173.10 & -163.36 \\
\hline W & 11 & F534 & 42 & 12.38 & 119 & 48.50 & 4720.0 & 979922.13 & -11.73 & 0.13 & 1.08 & -173.00 & $-162 \cdot 74$ \\
\hline$W$ & 12 & G644 & 42 & 11.37 & 119 & 48.23 & 5060.0 & 979895.09 & -5.31 & 1.03 & 2.37 & -176.93 & -166.01 \\
\hline $\mathrm{W}$ & 13 & G644 & 42 & 10.46 & 119 & 47.58 & 5214.0 & 979883.00 & -1.56 & 1.08 & 2.92 & -177.90 & -166.68 \\
\hline $\mathrm{W}$ & 14 & G634 & 42 & 10.46 & 119 & 46.75 & 5068.0 & 979896.74 & -1.54 & 0.06 & 1.05 & -174.76 & -163.73 \\
\hline$W$ & 15 & G634 & 42 & 10.98 & 119 & 46.64 & 5064.0 & 979897.18 & -2.26 & 0.14 & 1.02 & -175.38 & -164.35 \\
\hline $\mathrm{W}$ & 16 & G633 & 42 & 15.04 & 119 & 46.59 & 4710.0 & 979930.33 & -8.45 & 0.12 & 1.39 & -169.07 & -158.85 \\
\hline$W$ & 17 & W534 & 42 & 14.90 & 119 & 45.91 & 4733.0 & 979928.62 & -7.79 & 0.15 & 1.63 & -168.96 & -158.70 \\
\hline $\mathrm{W}$ & 18 & G634 & 42 & 12.90 & 119 & 45.14 & 4745.0 & 979922.64 & -9.65 & 0.51 & 2.24 & -170.62 & -160.37 \\
\hline $\mathrm{W}$ & 19 & G533 & 42 & 15.55 & 119 & 47.15 & 4496.0 & 979945.04 & -14.62 & 0.01 & 1.53 & -167.77 & -158.02 \\
\hline $\mathrm{W}$ & 20 & G534 & 42 & 16.46 & 119 & 46.84 & 4488.0 & 979947.31 & -14.47 & 0.06 & 1.94 & -166.94 & -157.23 \\
\hline $\mathrm{W}$ & 21 & G534 & 42 & 16.11 & 119 & 47.14 & 4484.0 & 979946.70 & -14.93 & 0.02 & 1.63 & -167.57 & -157.85 \\
\hline $\mathrm{W}$ & 22 & $\times 524$ & 42 & 18.74 & 119 & 47.32 & 4474.0 & 979950.49 & -16.02 & 0.34 & 3.45 & -166.50 & -156.92 \\
\hline$W$ & 23 & G634 & 42 & 13.86 & 119 & 48.17 & 4508.0 & 979940.19 & -15.81 & 0.04 & 1.27 & -169.64 & -159.84 \\
\hline $\mathrm{W}$ & 24 & G644 & 42 & 13.53 & 119 & 49.55 & 4539.0 & 979936.83 & -15.77 & 0.12 & 1.20 & -170.73 & -160.86 \\
\hline$W$ & 25 & G534 & 42 & 10.84 & 119 & 50.18 & 4483.0 & 979929.12 & -24.71 & 0.01 & 0.90 & -178.05 & -168.29 \\
\hline$W$ & 26 & W554 & 42 & 11.74 & 119 & 50.17 & 4484.0 & 979932.08 & -23.01 & 0.01 & 1.01 & -176.27 & -166.51 \\
\hline $\mathrm{W}$ & 27 & W534 & 42 & 12.94 & 119 & 50.58 & 4482.0 & 979934.55 & -22.52 & 0.01 & 1.23 & -175.50 & -165.76 \\
\hline $\mathrm{W}$ & 28 & F534 & 42 & 9.78 & 119 & 54.07 & 4530.0 & 979919.97 & -27.86 & 0.01 & 1.76 & -181.95 & -172.14 \\
\hline$W$ & 29 & B124 & 42 & 9.20 & 119 & 54.93 & 4498.4 & 979922.04 & -27.89 & 0.57 & 3.30 & -179.37 & -169.72 \\
\hline $\mathrm{W}$ & 30 & B124 & 42 & 9.09 & 119 & 53.48 & 4494.2 & 979916.53 & -33.63 & 0.01 & 1.13 & -187.13 & -177.35 \\
\hline W & 31 & B124 & 42 & 9.08 & 119 & 52.02 & 4489.4 & 979919.57 & -31.03 & 0.01 & 0.82 & -184.67 & -174.88 \\
\hline$W$ & 32 & F534 & 42 & 8.64 & 119 & 51.94 & 88.0 & 79919.41 & -30.66 & 0.01 & 0.78 & -184.29 & -174.51 \\
\hline $\mathrm{W}$ & 33 & F534 & 42 & 7.97 & 119 & 51.86 & 4496.0 & 979918.64 & -29.68 & 0.01 & 0.73 & -183.64 & -173.84 \\
\hline $\mathrm{W}$ & 34 & F534 & 42 & 8.02 & 119 & 53.09 & 4489.0 & 979914.78 & -34.27 & 0.01 & 0.85 & -187.86 & -178.09 \\
\hline $\mathrm{W}$ & 36 & G534 & 42 & 5.44 & 119 & 54.59 & 4489.0 & 979917.04 & -28.15 & 0.01 & 0.97 & -181.63 & -171.86 \\
\hline$W$ & 37 & F534 & 42 & 4.65 & 119 & 54.36 & 4497.0 & 979917.46 & -25.79 & 0.01 & 1.11 & -179.40 & -169.62 \\
\hline W & 39 & G534 & 42 & 7.34 & 119 & 54.40 & 4486.0 & 979916.17 & -32.14 & 0.01 & 1.07 & -185.42 & -175.66 \\
\hline $\mathrm{W}$ & 40 & F534 & 42 & 7.78 & 119 & 54.42 & 4485.0 & 979915.17 & -33.89 & 0.01 & 1.17 & -187.03 & -177.28 \\
\hline $\mathrm{W}$ & 41 & F534 & 42 & 8.22 & 119 & 54.31 & 4488.0 & 979914.39 & -35.05 & 0.01 & 1.25 & -188.22 & -178.46 \\
\hline $\mathrm{W}$ & 42 & N324 & 42 & 8.64 & 119 & 55.89 & 4510.0 & 979923.53 & -24.47 & 1.77 & 6.22 & -173.42 & -163.94 \\
\hline W & 43 & F534 & 42 & 7.78 & 119 & 56.24 & 4492.0 & 979923.84 & -24.57 & 0.65 & 4.94 & -174.18 & -164.65 \\
\hline$W$ & 44 & B124 & 42 & 5.91 & 119 & 57.04 & 4533.8 & 979925.52 & -16.16 & 0.40 & 3.29 & -166.84 & -159.13 \\
\hline $\mathrm{W}$ & 46 & F534 & 42 & 4.43 & 119 & 57.72 & 4602.0 & 979921.77 & -11.29 & 0.34 & 2.51 & -167.10 & -157.18 \\
\hline $\mathrm{W}$ & 47 & G634 & 42 & 3.10 & 119 & 58.12 & 4624.0 & 979917.54 & -11.46 & 0.66 & 2.73 & -167.80 & $-157,85$ \\
\hline$W$ & 49 & F534 & 42 & 10.84 & 119 & 51.03 & 4484.0 & 979927.49 & -26.25 & 0.01 & 0.94 & -179.58 & -169.82 \\
\hline$W$ & 50 & G534 & 42 & 11.90 & 119 & 51.17 & 4481.0 & 979930.24 & -25.37 & 0.01 & 1.19 & -178.35 & -168.61 \\
\hline $\mathrm{W}$ & 52 & G534 & 42 & 9.08 & 119 & 54.25 & 4494.0 & 979917.49 & -32.68 & 0.01 & 1.59 & -185.71 & -175.96 \\
\hline $\mathrm{W}$ & 53 & G534 & 42 & 9.08 & 119 & 53.07 & 4495.0 & 979916.67 & -33.40 & 0.01 & 1.00 & -187.05 & -177.27 \\
\hline $\mathrm{W}$ & 54 & F534 & 42 & 8.65 & 119 & 53.08 & 4491.0 & 979915.39 & -34.41 & 0.01 & 0.93 & -187.99 & -178.22 \\
\hline $\mathrm{W}$ & 55 & G534 & 42 & 8.02 & 119 & 53.69 & 4488.0 & 979914.20 & -34.94 & 0.01 & 0.97 & -188.38 & $-178,61$ \\
\hline $\mathrm{W}$ & 56 & G534 & 42 & 9.96 & 119 & 52.62 & 4492.0 & 979921.16 & -30.51 & 0.01 & 1.08 & -183.98 & -174.21 \\
\hline
\end{tabular}


TABLE 1--CONTINUED

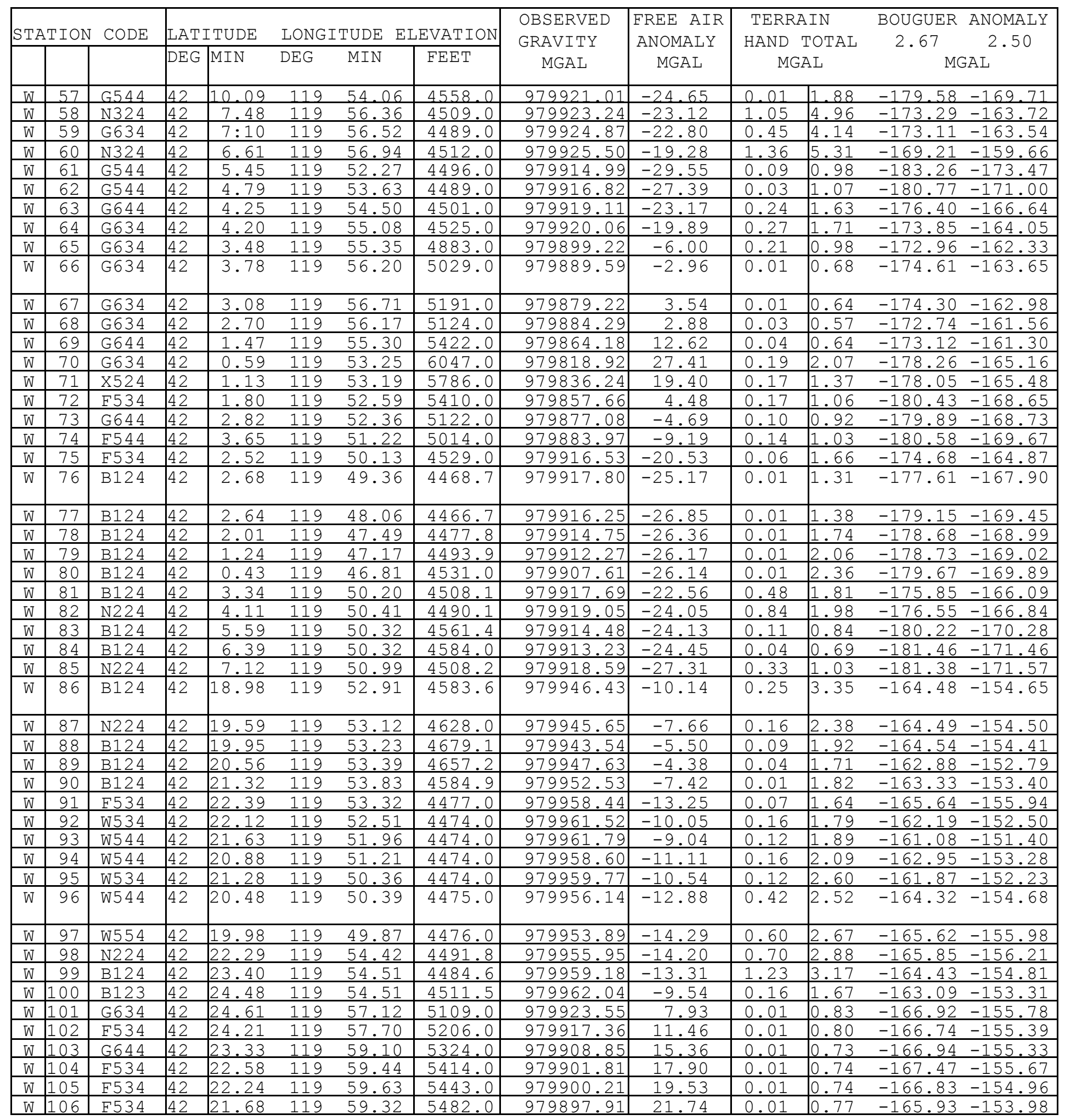


TABLE 1-CONTINUED

\begin{tabular}{|c|c|c|c|c|c|c|c|c|c|c|c|c|}
\hline \multirow{2}{*}{\multicolumn{2}{|c|}{ STATION }} & \multirow[t]{2}{*}{ CODE } & \multicolumn{2}{|c|}{ LATITUDE } & \multicolumn{3}{|c|}{ LONGITUDE ELEVATION } & \multirow{3}{*}{$\begin{array}{c}\text { OBSERVED } \\
\text { GRAVITY } \\
\text { MGAL } \\
979882.99 \\
\end{array}$} & \multirow{3}{*}{\begin{tabular}{|c} 
FREE AIR \\
ANOMALY \\
MGAL
\end{tabular}} & \multirow{2}{*}{\multicolumn{2}{|c|}{$\begin{array}{c}\text { TERRAIN } \\
\text { HAND TOTAL } \\
\text { MGAL }\end{array}$}} & \multirow{2}{*}{$\begin{array}{cc}\text { BOUGUER } & \text { ANOMALY } \\
2.67 & 2.50 \\
\text { MGAL }\end{array}$} \\
\hline & & & DEG & MIN & $\mathrm{DEG}$ & MIN & FEET & & & & & \\
\hline $\mathrm{W}$ & 107 & F534 & 42 & 19.61 & 119 & 57.41 & 5648.0 & & & 0.17 & .24 & $-167.35-155.07$ \\
\hline W & 108 & F534 & 42 & 21.54 & 120 & 0.14 & 5530.0 & 979893.73 & 22.28 & 0.01 & 0.76 & $-167.03-154.98$ \\
\hline $\mathrm{W}$ & 109 & G634 & 42 & 20.53 & 120 & 1.01 & 5631.0 & 979883.33 & 22.88 & 0.01 & 0.81 & $-169.83-157.56$ \\
\hline $\mathrm{W}$ & 110 & B224 & 42 & 19.94 & 120 & 1.75 & 5713.0 & 979877.43 & 25.57 & 0.02 & 0.92 & $-169.84-157.40$ \\
\hline W & 111 & G634 & 42 & 18.77 & 120 & 2.47 & 5763.0 & 979871.32 & 25.91 & 0.01 & 1.08 & $-171.05-158.51$ \\
\hline $\mathrm{W}$ & 112 & G634 & 42 & 17.15 & 120 & 4.20 & 5661.0 & 979874.00 & 21.43 & 0.02 & 1.16 & $-171.96-159.65$ \\
\hline W & 113 & B124 & 42 & 12.89 & 120 & 4.88 & 5454.8 & 979880.98 & 15.41 & 0.26 & 1.00 & $-171.09-159.22$ \\
\hline $\mathrm{W}$ & 114 & B124 & 42 & 26.64 & 119 & 49.06 & 4477.3 & 979955.67 & -22.36 & 0.06 & 4.92 & $-171.49-161.99$ \\
\hline $\mathrm{W}$ & 115 & B224 & 42 & 26.67 & 119 & 50.00 & 4473.3 & 979956.49 & -21.96 & 0.01 & 2.94 & $-172.92-163.31$ \\
\hline $\mathrm{W}$ & 116 & B124 & 42 & 26.74 & 119 & 51.30 & 4476.2 & 979961.97 & -16.31 & 0.01 & 1.83 & $-168.49-158.80$ \\
\hline $\mathrm{W}$ & 117 & B124 & 42 & 26.37 & 119 & 53.06 & 4474.1 & 979969.24 & -8.69 & 0.01 & 1.32 & $-161.31-151.59$ \\
\hline W & 118 & B224 & 42 & 25.50 & 119 & 53.08 & 4490.9 & 979964.03 & -11.01 & 0.01 & 1.33 & $-164.19-154.43$ \\
\hline W & 119 & B124 & 42 & 25.27 & 119 & 54.27 & 4514.5 & 979963.47 & -9.01 & 0.01 & 1.27 & $-163.06-153.25$ \\
\hline $\mathrm{W}$ & 120 & G644 & 42 & 19.64 & 119 & 54.22 & 4753.0 & 979936.40 & -5.23 & 0.39 & 3.78 & $-164.94-154.77$ \\
\hline $\mathrm{W}$ & 121 & G644 & 42 & 19.96 & 119 & 52.38 & 4781.0 & 979938.05 & -1.43 & 0.10 & 1.50 & $-164.38-154.00$ \\
\hline $\mathrm{W}$ & 122 & G644 & 42 & 19.34 & 119 & 52.22 & 4532.0 & 979950.57 & -11.38 & 0.36 & 2.44 & $-164.86-155.09$ \\
\hline$W$ & 123 & G534 & 42 & 19.00 & 119 & 52.26 & 4482.0 & 979953.01 & -13.13 & 0.06 & 2.51 & $-164.82-155.17$ \\
\hline $\mathrm{W}$ & 124 & $\times 524$ & 42 & 18.73 & 119 & 51.38 & 4479.0 & 979950.51 & -15.51 & 0.17 & 2.10 & $-167.51-157.84$ \\
\hline $\mathrm{W}$ & 125 & W534 & 42 & 18.50 & 119 & 50.79 & 4479.0 & 979949.25 & -16.43 & 0.23 & 1.91 & $-168.62-158.93$ \\
\hline $\mathrm{W}$ & 126 & W544 & 42 & 18.68 & 119 & 50.34 & 4478.0 & 979950.85 & -15.19 & 0.17 & 1.82 & $-167.44-157.75$ \\
\hline $\mathrm{W}$ & 127 & N324 & 42 & 17.93 & 119 & 52.37 & 4501.1 & 979944.49 & -18.26 & 0.36 & 4.17 & $-168.95-159.36$ \\
\hline W & 128 & D4 34 & 42 & 17.22 & 119 & 52.01 & 4489.0 & 979944.77 & -18.05 & 1.06 & 4.11 & $-168.39-158.82$ \\
\hline W & 129 & B124 & 42 & 16.47 & 119 & 51.83 & 4481.9 & 979945.09 & -17.27 & 0.23 & 3.02 & $-168.45-158.82$ \\
\hline $\mathrm{W}$ & 130 & R324 & 42 & 16.06 & 119 & 52.55 & 4481.0 & 979942.07 & -19.77 & 0.58 & 6.50 & $-167.44-158.04$ \\
\hline $\mathrm{W}$ & 131 & B124 & 42 & 14.93 & 119 & 52.47 & 4496.8 & 979939.86 & -18.80 & 0.39 & 5.94 & $-167.57-158.10$ \\
\hline $\mathrm{W}$ & 132 & B124 & 42 & 11.46 & 119 & 53.88 & 4630.8 & 979922.13 & -18.74 & 0.47 & 4.29 & $-173.75-163.88$ \\
\hline $\mathrm{W}$ & 133 & B124 & 42 & 12.27 & 119 & 53.51 & 4551.3 & 979929.66 & -19.89 & 0.70 & 5.84 & $-170.63-161.03$ \\
\hline $\mathrm{W}$ & 134 & B124 & 42 & 13.06 & 119 & 52.77 & 4534.1 & 979933.08 & -19.27 & 0.23 & 4.10 & $-171.16-161.49$ \\
\hline $\mathrm{W}$ & 135 & B124 & 42 & 14.03 & 119 & 52.71 & 4516.1 & 979936.96 & -18.54 & 0.60 & 5.94 & $-167.97-158.46$ \\
\hline $\mathrm{W}$ & 136 & G644 & 42 & 20.38 & 119 & 47.44 & 4532.0 & 979947.21 & -16.30 & 0.88 & 6.33 & $-165.89-156.37$ \\
\hline $\mathrm{W}$ & 137 & $\times 524$ & 42 & 19.14 & 119 & 47.48 & 4477.0 & 979948.43 & -18.39 & 0.25 & 3.54 & $-168.89-159.31$ \\
\hline W & 138 & G644 & 42 & 13.73 & 119 & 44.71 & 4946.0 & 979910.92 & -3.72 & 0.20 & 1.69 & $-172.12-161.40$ \\
\hline $\mathrm{W}$ & 139 & G634 & 42 & 12.15 & 119 & 44.09 & 5274.0 & 979886.61 & 5.16 & 0.08 & 1.24 & $-174.92-163.46$ \\
\hline $\mathrm{W}$ & 140 & F534 & 42 & 11.53 & 119 & 43.72 & 5348.0 & 979880.04 & 6.47 & 0.02 & 1.16 & $-176.22-164.59$ \\
\hline $\mathrm{W}$ & 141 & W534 & 42 & 12.64 & 119 & 42.80 & 5380.0 & 979880.71 & 8.49 & 0.02 & 1.38 & $-175.07-163.38$ \\
\hline$W$ & 142 & G634 & 42 & 13.48 & 119 & 42.50 & 5411.0 & 919882.55 & 11.99 & 0.53 & 2.25 & $-171.77-160.07$ \\
\hline $\mathrm{W}$ & 143 & G644 & 42 & 14.91 & 119 & 42.61 & 5480.0 & 979882.33 & 16.11 & 0.38 & 2.06 & $-170.19-158.33$ \\
\hline $\mathrm{W}$ & 144 & $\times 624$ & 42 & 15.25 & 119 & 43.01 & 5352.0 & 979890.06 & 11.30 & 0.64 & 2.45 & $-170.23-158.68$ \\
\hline W & 145 & G634 & 42 & 10.57 & 119 & 44.09 & 5121.0 & 979895.40 & 1.94 & 0.11 & 1.46 & $-172.68-161.56$ \\
\hline $\mathrm{W}$ & 146 & G744 & 42 & 9.66 & 119 & 44.39 & 5223.0 & 979887.31 & 4.79 & 0.38 & 1.78 & $-173.00-161.68$ \\
\hline $\mathrm{W}$ & 147 & B124 & 42 & 7.36 & 119 & 46.47 & 4567.2 & 979920.37 & -20.34 & 0.02 & 1.29 & $-176.18-166.26$ \\
\hline $\mathrm{W}$ & 148 & B124 & 42 & 9.76 & 119 & 47.74 & 4494.7 & 979928.84 & -22.28 & 0.02 & 1.28 & $-175.64-165.88$ \\
\hline $\mathrm{W}$ & 149 & B124 & 42 & 8.93 & 119 & 47.38 & 4513.0 & 979925.84 & -22.31 & 0.01 & 1.11 & $-176.47-166.65$ \\
\hline $\mathrm{W}$ & 150 & B124 & 42 & 8.09 & 119 & 46.93 & 4534.6 & 979923.27 & -21.60 & 0.01 & 1.14 & $-176.47-166.61$ \\
\hline $\mathrm{W}$ & 151 & F534 & 42 & 6.33 & 119 & 46.76 & 4605.0 & 979917.55 & -18.07 & 0.14 & 1.26 & $-175.23-165.23$ \\
\hline $\mathrm{W}$ & 152 & F534 & 42 & 5.56 & 119 & 46.83 & 4509.0 & 979921.58 & -21.91 & 0.03 & 1.41 & $-175.63-165.84$ \\
\hline W & 153 & F534 & 42 & 4.09 & 119 & 46.47 & 4500.0 & 979919.72 & -22.41 & 0.02 & 2.09 & $-175.15-165.42$ \\
\hline $\mathrm{W}$ & 154 & G534 & 42 & 3.32 & 119 & 46.49 & 4484.0 & 979918.50 & -23.99 & 0.02 & 2.49 & $-175.78-166.11$ \\
\hline $\mathrm{W}$ & 155 & F534 & 42 & 5.74 & 119 & 56.50 & 4504.0 & 979922.05 & -22.18 & 0.01 & 1.87 & $-175.27-165.52$ \\
\hline $\mathrm{W}$ & 156 & G634 & 42 & 2.00 & 119 & 59.25 & 4954.0 & 979895.23 & -1.11 & 0.41 & 1.67 & $-169.81-159.07$ \\
\hline
\end{tabular}


TABLE 1--CONTINUE

\begin{tabular}{|c|c|c|c|c|c|c|c|c|c|c|c|c|}
\hline & & & & & & & & OBSERVED & FREE AIR & TERF & IN & BOUGUER ANOMALY \\
\hline STA: & TION & $\mathrm{CODE}$ & $\mathrm{LAT}$ & [TUDE & LONG & TUDE E & EVATION & GRAVITY & ANOMALY & HAND & OTZ & 2.67 \\
\hline & & & DEG & MIN & $\mathrm{DEG}$ & MIN & FEET & & MGAL & & & \\
\hline$W$ & 157 & G634 & 42 & 1.19 & 119 & 58.30 & 5276.0 & 979873.52 & 8.66 & 0.09 & .6 & $-172.06-160.55$ \\
\hline$W$ & 158 & N324 & 42 & 1.64 & 119 & 59.87 & 5230.0 & 979878.20 & 8.34 & 0.31 & 1.20 & $-170.27-158.90$ \\
\hline$W$ & 159 & N224 & 42 & 0.68 & 120 & 0.55 & 5544.0 & 979858.97 & 20.06 & -0.07 & 0.76 & $-169.73-157.65$ \\
\hline$W$ & 160 & N224 & 42 & 2.51 & 120 & 1.22 & 5774.0 & 979847.22 & 27.19 & 0.26 & 1.20 & $-170.03-157.47$ \\
\hline$W$ & 161 & $\mathrm{~B} 124$ & 42 & 3.09 & 120 & 1.84 & 5745.2 & 979850.39 & 26.78 & 0.03 & 0.81 & $-169.84-157.32$ \\
\hline $\mathrm{W}$ & 162 & F534 & 42 & 9.35 & 119 & 48.30 & 4487.0 & 979926.86 & -24.37 & 0.01 & 0.94 & $-177.81-168.04$ \\
\hline $\mathrm{W}$ & 163 & G534 & 42 & 8.22 & 119 & 48.91 & 4486.0 & 979923.56 & -26.07 & 0.01 & 0.78 & $-179.63-169.85$ \\
\hline $\mathrm{W}$ & 164 & B124 & 42 & 10.54 & 119 & 56.02 & 4746.7 & 979916.39 & -12.21 & 2.75 & 7.30 & $-168.18-158.25$ \\
\hline$W$ & 165 & $\mathrm{~N} 434$ & 42 & 10.49 & 119 & 57.22 & 4898.0 & 979908.32 & -5.98 & 1.28 & 4.46 & $-169.98-159.53$ \\
\hline $\mathrm{W}$ & 166 & B124 & 42 & 10.89 & 119 & 58.29 & 4955.1 & 979904.40 & -5.14 & 0.54 & 3.31 & $-172.24-161.60$ \\
\hline $\mathrm{W}$ & 167 & N224 & 42 & 11.11 & 119 & 59.41 & 4963.4 & 979904.38 & -4.70 & 2.69 & 5.24 & $-170.15-159.61$ \\
\hline$W$ & 168 & N324 & 42 & 12.53 & 120 & 1.97 & 5224.0 & 979893.28 & 6.56 & 0.33 & 1.37 & $-171.67-160.33$ \\
\hline$W$ & 169 & B124 & 42 & 13.00 & 120 & 2.90 & 5296.7 & 979888.90 & 8.31 & 0.62 & 1.54 & $-172.24-160.75$ \\
\hline WA & 1 & $\mathrm{~B} 122$ & 42 & 10.47 & 119 & 51.67 & 4485.9 & 979924.20 & 28.81 & 0.01 & 0.97 & $-182.18-172.41$ \\
\hline WA & 2 & $\mathrm{P} 124$ & 42 & 10.47 & 119 & 51.74 & 4486.6 & 979925.13 & -27.81 & 0.01 & 0.99 & $-181.19-171.42$ \\
\hline WA & 3 & $\mathrm{P} 124$ & 42 & 10.47 & 119 & 51.80 & 4486.9 & 979924.96 & -27.95 & 0.01 & 1.00 & $-181.33-171.56$ \\
\hline WA & 4 & $\mathrm{P} 124$ & 42 & 10.47 & 119 & 51.88 & 4486.7 & 979924.79 & -28.14 & 0.01 & 1.01 & $-181.49-171.73$ \\
\hline WA & 5 & $\mathrm{P} 124$ & 42 & 10.47 & 119 & 51.93 & 4487.9 & 979924.54 & -28.28 & 0.01 & 1.02 & $-181.66-171.90$ \\
\hline WA & 6 & $\mathrm{P} 124$ & 42 & 10.47 & 119 & 51.99 & 4490.1 & 979924.20 & -28.41 & 0.01 & 1.03 & $-181.86-172.09$ \\
\hline WA & 7 & $\mathrm{P} 124$ & 42 & 10.47 & 119 & 52.06 & 4492.6 & 979923.90 & -28.48 & 0.01 & 1.05 & $-182.00-172.23$ \\
\hline WA & 8 & & 42 & 10.48 & & & 4.8 & .04 & - & & & $-182.21-172.43$ \\
\hline WA & 9 & B122 & 42 & 10.49 & 119 & 52.21 & 4495.7 & 979923.35 & -28.76 & 0.01 & 1.10 & $-182.34-172.56$ \\
\hline WA & 10 & $\mathrm{P} 124$ & 42 & 10.47 & 119 & 51.59 & 4486.8 & 979925.39 & -27.53 & 0.01 & 0.96 & $-180.94-171.17$ \\
\hline WA & 11 & $\mathrm{P} 124$ & 42 & 10.47 & 119 & 51.52 & 4487.2 & 979925.58 & -27.31 & 0.01 & 0.95 & $-180.75-170.98$ \\
\hline WA & 12 & $\mathrm{P} 124$ & 42 & 10.47 & 119 & 51.46 & 4487.1 & 979925.72 & -27.17 & 0.01 & 0.94 & $-180.61-170.84$ \\
\hline WA & 13 & $\mathrm{P} 124$ & 42 & 10.47 & 119 & 51.39 & 4487.3 & 979925.90 & -26.98 & 0.01 & 0.93 & $-180.44-170.67$ \\
\hline WA & 14 & $\mathrm{P} 124$ & 42 & 10.47 & 119 & 51.32 & 4486.8 & 979926.02 & -26.90 & 0.01 & 0.92 & $-180.35-170.58$ \\
\hline WA & 15 & $\mathrm{P} 124$ & 42 & 10.47 & 119 & 51.25 & 4486.8 & 979926.08 & -26.84 & 0.01 & 0.91 & $-180.30-170.53$ \\
\hline WA & 16 & $\mathrm{P} 124$ & 42 & 10.47 & 119 & 51.17 & 4486.8 & 979926.15 & -26.77 & 0.01 & 0.90 & $-180.24-170.47$ \\
\hline WA & 17 & P124 & 42 & 10.47 & 119 & 51.10 & 4486.8 & 979926.29 & -26.63 & 0.01 & 0.89 & $-180.11-170.33$ \\
\hline WA & 18 & $\mathrm{P} 123$ & 42 & 10.47 & 119 & 51.03 & 86.7 & 979926.40 & -26.53 & 0.01 & 0.89 & $-180.01-170.24$ \\
\hline WA & 19 & $\mathrm{P} 124$ & 42 & 10.47 & 119 & 50.98 & 4487.0 & 979926.48 & -26.42 & 0.01 & 0.88 & $-179.91-170.14$ \\
\hline WA & 20 & $\mathrm{P} 124$ & 42 & 10.47 & 119 & 50.91 & 4486.8 & 979926.64 & -26.28 & 0.01 & 0.88 & $-179.77-170.00$ \\
\hline WA & 21 & $\mathrm{P} 124$ & 42 & 10.47 & 119 & 50.83 & 4487.4 & 979926.78 & -26.09 & 0.01 & 0.87 & $-179.61-169.84$ \\
\hline WA & 22 & $\mathrm{P} 124$ & 42 & 10.47 & 119 & 50.76 & 4486.7 & 979926.99 & -25.94 & 0.01 & 0.87 & $-179.44-169.67$ \\
\hline WA & 23 & $\mathrm{P} 124$ & 42 & 10.47 & 119 & 50.70 & 4487.4 & 979927.03 & -25.84 & 0.01 & 0.86 & $-179.37-169.59$ \\
\hline WA & 24 & $\mathrm{P} 124$ & 42 & 10.47 & 119 & 50.63 & 4486.9 & 979927.24 & -25.67 & 0.01 & 0.86 & $-179.18-169.41$ \\
\hline WA & 25 & $\mathrm{P} 124$ & 42 & 10.47 & 119 & 50.58 & 4486.8 & 979927.31 & -25.61 & 0.01 & 0.86 & $-179.12-169.35$ \\
\hline WA & 26 & $\mathrm{~B} 123$ & 42 & 10.48 & 119 & 50.52 & 4483.2 & 979927.64 & -25.64 & 0.01 & 0.86 & $-179.02-169.26$ \\
\hline WA & 27 & P124 & 42 & 10.47 & 119 & 50.46 & 4486.9 & 979927.46 & -25.45 & 0.01 & 0.85 & $-178.98-169.20$ \\
\hline WA & 28 & $\mathrm{P} 124$ & 42 & 10.47 & 119 & 50.40 & 4481.2 & 919921.64 & -25.25 & 0.01 & 0.85 & $-178.78-169.00$ \\
\hline WA & 29 & $\mathrm{P} 124$ & 42 & 10.47 & 119 & 50.34 & 4486.9 & 979927.74 & -25.17 & 0.01 & 0.85 & $-178.69-168.92$ \\
\hline WA & 30 & $\mathrm{P} 124$ & 42 & 10.47 & 119 & 50.29 & 4487.0 & 979927.86 & -25.04 & 0.01 & 0.85 & $-178.56-168.79$ \\
\hline WA & 31 & $\mathrm{P} 124$ & 42 & 10.47 & 119 & 50.23 & 4486.9 & 979927.96 & -24.95 & 0.01 & 0.85 & $-178.47-168.70$ \\
\hline WA & 32 & $\mathrm{P} 124$ & 42 & 10.47 & 119 & 50.17 & 4486.8 & 979928.10 & -24.82 & 0.01 & 0.85 & $-178.34-168.56$ \\
\hline WA & 33 & $\mathrm{P} 124$ & 42 & 10.47 & 119 & 50.11 & 4486.8 & 979928.23 & -24.69 & 0.01 & 0.85 & $-178.21-168.43$ \\
\hline WA & 34 & $\mathrm{P} 124$ & 42 & 10.47 & 119 & 50.05 & 4486.6 & 979928.40 & -24.54 & 0.01 & 0.86 & $-178.05-168.27$ \\
\hline WA & 35 & $\mathrm{P} 124$ & 42 & 10.47 & 119 & 49.99 & 4486.8 & 979928.48 & -24.44 & 0.01 & 0.86 & $-177.95-168.18$ \\
\hline WA & 36 & $\mathrm{P} 124$ & 42 & 10.47 & 119 & 49.93 & 4486.9 & 979928.59 & -24.32 & 0.01 & 0.86 & $-177.83-168.06$ \\
\hline WA & 37 & $\mathrm{P} 124$ & 42 & 10.48 & 119 & 49.87 & 4486.9 & 979928.70 & -24.23 & 0.01 & 0.87 & $-177.74-167.96$ \\
\hline
\end{tabular}


TABLE 1--CONTINUED

\begin{tabular}{|c|c|c|c|c|c|c|c|c|c|c|c|c|}
\hline \multirow{3}{*}{\multicolumn{2}{|c|}{ STATION CODE }} & & & & & & \multirow{4}{*}{$\begin{array}{c}\text { OBSERVED } \\
\text { GRAVITY } \\
\text { MGAL } \\
979928.79\end{array}$} & \multirow{4}{*}{$\begin{array}{c}\text { FREE AIR } \\
\text { ANOMALY } \\
\text { MGAL } \\
-24.15\end{array}$} & \multirow{3}{*}{\multicolumn{2}{|c|}{$\begin{array}{c}\text { TERRAIN } \\
\text { HAND TOTAL } \\
\text { MGAL }\end{array}$}} & \multirow{3}{*}{\multicolumn{2}{|c|}{$\begin{array}{cc}\text { BOUGUER } & \text { ANOMALY } \\
2.67 & 2.50 \\
\text { MGAL }\end{array}$}} \\
\hline & & \multicolumn{2}{|c|}{ LATITUDE } & \multicolumn{3}{|c|}{ LONGITUDE ELEVATION } & & & & & & \\
\hline & & $\mathrm{DEG}$ & MIN & $\mathrm{DEG}$ & MIN & FEET & & & & & & \\
\hline WA 38 & $\mathrm{P} 124$ & 42 & 10.48 & 119 & 49.82 & 4486.8 & & & 0.01 & 0.87 & -177.65 & -167.88 \\
\hline WA 39 & $\mathrm{P} 124$ & 42 & 10.48 & 119 & 49.76 & 4486.8 & 979928.90 & -24.04 & 0.01 & 0.87 & -177.54 & -167.76 \\
\hline WA 40 & $\mathrm{P} 124$ & 42 & 10.45 & 119 & 49.70 & 4486.9 & 979928.94 & -23.99 & 0.01 & 0.88 & -177.48 & -167.71 \\
\hline WA 41 & $\mathrm{P} 124$ & 42 & 10.48 & 119 & 49.64 & 4487.1 & 979929.05 & -23.86 & 0.01 & 0.89 & -177.36 & -167.58 \\
\hline WA 42 & $\mathrm{P} 124$ & 42 & 10.48 & 119 & 49.58 & 4487.0 & 979929.18 & -23.74 & 0.01 & 0.89 & -177.23 & -167.45 \\
\hline WA 43 & $\mathrm{P} 124$ & 42 & 10.48 & 119 & 49.52 & 4487.0 & 979929.20 & -23.72 & 0.01 & 0.90 & -177.20 & -167.43 \\
\hline WA 44 & $\mathrm{P} 124$ & 42 & 10.48 & 119 & 49.47 & 4487.0 & 979929.18 & -23.74 & 0.01 & 0.90 & -177.21 & -167.44 \\
\hline WA 45 & P124 & 42 & 10.48 & 119 & 49.41 & 4487.1 & 979929.18 & -23.73 & 0.01 & 0.91 & -177.20 & -167.43 \\
\hline WA 46 & $\mathrm{P} 124$ & 42 & 10.48 & 119 & 49.33 & 4486.8 & 979929.19 & -23.75 & 0.01 & 0.92 & -177.20 & -167.83 \\
\hline WA 47 & P124 & 42 & 10.48 & 119 & 49.28 & 4485.2 & 979929.37 & -23.72 & 0.01 & 0.93 & -177.10 & -167.34 \\
\hline WA 48 & $\mathrm{P} 124$ & 42 & 10.48 & 119 & 49.22 & 4486.5 & 979929.30 & 23.66 & 0.01 & 0.94 & -177.08 & -167.31 \\
\hline WA 49 & $\mathrm{P} 124$ & 42 & 10.48 & 119 & 49.17 & 4486.4 & 979929.40 & -23.57 & 0.01 & 0.96 & -176.97 & -167.20 \\
\hline WA 50 & $\mathrm{P} 124$ & 42 & 10.48 & 119 & 49.10 & 4486.6 & 979929.48 & -23.48 & 0.01 & 0.96 & -176.88 & -167.11 \\
\hline WA 51 & $\mathrm{P} 124$ & 42 & 10.48 & 119 & 49.04 & 4486.6 & 979929.59 & -23.37 & 0.01 & 0.92 & -176.82 & -167.05 \\
\hline WA 52 & $\mathrm{P} 124$ & 42 & 10.48 & 119 & 48.99 & 4486.7 & 979929.59 & -23.36 & 0.01 & 0.99 & -176.73 & -166.97 \\
\hline WA 53 & $\mathrm{P} 124$ & 42 & 10.48 & 119 & 48.93 & 4486.6 & 979929.52 & -23.44 & 0.01 & 1.01 & -176.79 & -167.03 \\
\hline WA 54 & P124 & 42 & 10.48 & 119 & 48.87 & 4487.5 & 979929.36 & -23.51 & 0.01 & 1.03 & -176.87 & -167.11 \\
\hline WA 55 & $\mathrm{P} 124$ & 42 & 10.48 & 119 & 48.81 & 4488.7 & 979929.26 & -23.50 & 0.01 & 1.06 & -176.88 & -167.11 \\
\hline WA 56 & $\mathrm{P} 124$ & 42 & 10.48 & 119 & 48.75 & 4489.8 & 979929.25 & -23.40 & 0.01 & 1.08 & -176.79 & -167.03 \\
\hline WA 57 & P124 & 42 & 10.48 & 119 & 48.69 & 4491.1 & 979929.23 & -23.30 & 0.01 & 1.11 & -176.71 & -166.94 \\
\hline WA 58 & $\mathrm{P} 124$ & 42 & 10.48 & 119 & 48.62 & 4491.5 & 979929.30 & -23.19 & 0.01 & 1.15 & -176.57 & -166.81 \\
\hline WA 59 & $\mathrm{P} 124$ & 42 & 10.48 & 119 & 48.56 & 4491.8 & 979929.42 & -23.05 & 0.01 & 1.18 & -176.41 & -166.65 \\
\hline WA 60 & $\mathrm{P} 124$ & 42 & 10.48 & 119 & 48.50 & 4491.6 & 979929.54 & -22.95 & 0.01 & 1.22 & -176.27 & -166.51 \\
\hline WA 61 & P124 & 42 & 10.48 & 119 & 48.44 & 4491.5 & 979929.68 & -22.81 & 0.03 & 1.27 & -176.07 & -166.31 \\
\hline WA 62 & $\mathrm{P} 124$ & 42 & 10.48 & 119 & 48.39 & 4491.5 & 979929.86 & -22.63 & 0.06 & 1.33 & -175.83 & -166.07 \\
\hline WA 63 & P124 & 42 & 10.48 & 119 & 48.32 & 4491.5 & 979930.06 & -22.43 & 0.14 & 1.46 & -175.51 & -165.76 \\
\hline WA 64 & $\mathrm{P} 124$ & 42 & 10.46 & 119 & 48.26 & 4491.5 & 979930.26 & -22.21 & 0.31 & 1.65 & -175.09 & -165.36 \\
\hline WA 65 & $\mathrm{P} 124$ & 42 & 10.44 & 119 & 48.21 & 4491.7 & 979930.40 & -22.02 & 0.40 & 1.76 & -174.80 & -165.07 \\
\hline WA 66 & $\mathrm{P} 124$ & 42 & 10.43 & 119 & 48.17 & 4493.6 & 979930.48 & -21.74 & 0.48 & 1.85 & -174.49 & -164.77 \\
\hline WA 67 & B122 & 42 & 10.43 & 119 & 48.12 & 4490.6 & 979930.92 & -21.59 & 0.57 & 2.01 & -174.08 & -164.37 \\
\hline WA 68 & $\mathrm{P} 124$ & 42 & 10.50 & $\perp \perp 9$ & 52.27 & 4496.3 & 919923.26 & -28.81 & 0.01 & 1.12 & -182.39 & -172.61 \\
\hline WA 69 & $\mathrm{P} 124$ & 42 & 10.51 & 119 & 52.33 & 4498.0 & 979923.07 & -28.86 & 0.01 & 1.14 & -182.48 & -172.70 \\
\hline WA 70 & $\mathrm{P} 124$ & 42 & 10.52 & 119 & 52.40 & 4499.2 & 979922.93 & -28.90 & 0.01 & 1.16 & -182.53 & -172.75 \\
\hline WA 71 & P124 & 42 & 10.52 & 119 & 52.46 & 4500.6 & 979922.84 & -28.86 & 0.01 & 1.18 & -182.52 & -172.74 \\
\hline WA 72 & $\mathrm{P} 124$ & 42 & 10.55 & 119 & 52.51 & 4502.0 & 979922.69 & -28.92 & 0.01 & 1.21 & -182.61 & -172.82 \\
\hline WA 73 & $\mathrm{P} 124$ & 42 & 10.56 & 119 & 52.57 & 4503.4 & 979922.59 & -28.91 & 0.01 & 1.23 & -182.62 & -172.83 \\
\hline WA 74 & $\mathrm{P} 124$ & 42 & 10.57 & 119 & 52.62 & 4504.7 & 979922.49 & -28.90 & 0.01 & 1.25 & -182.63 & -172.84 \\
\hline WA 75 & $\mathrm{P} 124$ & 42 & 10.58 & 119 & 52.68 & 4508.1 & 979922.27 & -28.82 & 0.01 & 1.28 & -182.64 & -172.85 \\
\hline WA 76 & P124 & 42 & 10.59 & 119 & 52.74 & 4513.6 & 979921.86 & -28.72 & 0.02 & 1.31 & -182.70 & -172.90 \\
\hline WA 78 & B124 & 42 & 10.60 & 119 & 52.80 & 4522.0 & 979921.27 & -28.54 & 0.03 & 1.34 & -182.78 & -172.96 \\
\hline WA 79 & $\mathrm{P} 124$ & 42 & 10.61 & 119 & 52.82 & 4525.9 & 979921.09 & -28.37 & 0.02 & 1.34 & -182.74 & -172.91 \\
\hline WA 80 & $\mathrm{P} 124$ & 42 & 10.62 & 119 & 52.90 & 4535.6 & 979920.48 & -28.08 & 0.02 & 1.37 & -182.75 & -172.91 \\
\hline WA 81 & $\mathrm{P} 124$ & 42 & 10.62 & 119 & 52.93 & 4540.5 & 979920.15 & -27.95 & 0.02 & 1.38 & -182.78 & -172.93 \\
\hline WA 82 & $\mathrm{P} 124$ & 42 & 10.63 & 119 & 52.98 & 4547.2 & 979919.81 & -27.67 & 0.07 & 1.45 & -182.66 & -172.79 \\
\hline WA 83 & P124 & 42 & 10.64 & 119 & 53.02 & 4552.3 & 979919.53 & -27.49 & 0.07 & 1.47 & -182.64 & -172.76 \\
\hline WA 84 & $\mathrm{P} 124$ & 42 & 10.65 & 119 & 53.07 & 4558.2 & 979919.21 & -27.27 & 0.07 & 1.50 & -182.59 & -172.70 \\
\hline WA 85 & $\mathrm{P} 124$ & 42 & 10.65 & 119 & 53.11 & 4563.4 & 979918.97 & -27.02 & 0.04 & 1.48 & -182.53 & -172.63 \\
\hline WA 86 & $\mathrm{P} 124$ & 42 & 10.65 & 119 & 53.18 & 4567.0 & 979918.91 & -26.74 & 0.05 & 1.54 & -182.32 & -172.42 \\
\hline WA 87 & P124 & 42 & 10.65 & 119 & 53.23 & 4568.9 & 979918.97 & -26.50 & 0.04 & 1.56 & -182.13 & -172.22 \\
\hline WA 88 & $\mathrm{P} 124$ & 42 & 10.65 & 119 & 53.29 & 4569.8 & 979919.08 & -26.31 & 0.05 & 1.61 & -181.91 & -172.01 \\
\hline
\end{tabular}


TABLE 1-CONTINUED

\begin{tabular}{|c|c|c|c|c|c|c|c|c|c|c|c|c|}
\hline & & & & & & & OBSERVED & FREE AIR & $\mathrm{TE}$ & $\mathrm{N}$ & BOUGUER & $\overline{\mathrm{NC}}$ \\
\hline STATION & CODE & LAT & ITUDE & $\mathrm{LONG}$ & [TUDE & EVATION & GRAVITY & ANOMALY & HAND & TOTAL & 2.67 & 2.50 \\
\hline & & DEG & MIN & DEG & MIN & FFFT & MGAL & MGAL & & & & \\
\hline WA 89 & $\mathrm{P} 124$ & 42 & 10.65 & 119 & 53.35 & 4570.1 & 979919.26 & -26.10 & 0.02 & 1.63 & $-181 \cdot 70$ & -171.79 \\
\hline WA 90 & P124 & 42 & 10.65 & 119 & 53.40 & 4570.6 & 979919.48 & -25.83 & 0.02 & 1.67 & -181.41 & -171.50 \\
\hline WA 91 & P124 & 42 & 10.65 & 119 & 53.46 & 4570.6 & 979919.73 & -25.58 & 0.01 & 1.71 & $-181 \cdot 11$ & $-171 \cdot 21$ \\
\hline WA 92 & $\mathrm{P} 124$ & 42 & 10.65 & 119 & 53.51 & 4571.0 & 979919.93 & -25.35 & 0.01 & 1.75 & -180.85 & -170.95 \\
\hline WA 93 & P124 & 42 & 10.65 & 119 & 53.57 & 4571.2 & 979920.17 & -25.09 & 0.03 & 1.83 & -180.52 & -170.62 \\
\hline WA 94 & P124 & 42 & 10.65 & 119 & 53.62 & 4569.2 & 979920.54 & -24.91 & 0.05 & 1.91 & -180.19 & -170.30 \\
\hline WA 95 & P124 & 42 & 10.65 & 119 & 53.68 & 4564.4 & 979921.11 & -24.79 & 0.03 & 1.97 & -179.85 & -169.98 \\
\hline WA 96 & $\mathrm{P} 124$ & 42 & 10.65 & 119 & 53.73 & 4559.9 & 979921.70 & -24.62 & 0.02 & 2.03 & -179.46 & -169.60 \\
\hline WA 97 & $\mathrm{P} 124$ & 42 & 10.65 & 119 & 53.78 & 4553.7 & 979922.46 & -24.44 & 0.02 & 2.12 & -178.98 & -169.14 \\
\hline WA 98 & P124 & 42 & 10.65 & 119 & 53.82 & 4548.8 & 979923.10 & -24.26 & 0.02 & 2.19 & -178.56 & -168.74 \\
\hline WA 99 & $\mathrm{P} 123$ & 42 & 10.66 & 119 & 53.88 & 4542.8 & 979924.11 & -23.83 & 0.02 & 2.32 & -177.80 & -168.00 \\
\hline WA100 & $\mathrm{P} 124$ & 42 & 10.65 & 119 & 53.95 & 4545.8 & 979924.23 & -23.42 & 0.02 & 2.41 & -177.40 & -167.60 \\
\hline WA1 01 & P124 & 42 & 10.65 & 119 & 54.00 & 4550.9 & 979924.14 & -23.03 & 0.02 & 2.49 & -177.11 & -167.30 \\
\hline WA102 & P124 & 42 & 10.65 & 119 & 54.06 & 4560.1 & 979923.70 & -22.60 & 0.03 & 2.58 & -176.91 & -167.08 \\
\hline WA103 & $\mathrm{P} 124$ & 42 & 10.65 & 119 & 54.10 & 4565.3 & 979923.46 & -22.35 & 0.08 & 2.68 & -176.73 & -166.90 \\
\hline WA1 04 & $\mathrm{P} 124$ & 42 & 10.65 & 119 & 54.14 & 4570.0 & 979923.34 & -22.03 & 0.07 & 2.73 & -176.52 & -166.68 \\
\hline WA105 & $\mathrm{P} 124$ & 42 & 10.65 & 119 & 54.19 & 4572.7 & 979923.56 & -21.56 & 0.05 & 2.80 & -176.07 & -166.23 \\
\hline WA106 & $\mathrm{P} 124$ & 42 & 10.65 & 119 & 54.26 & 4574.0 & 979923.98 & -21.01 & 0.09 & 2.99 & -175.38 & -165.55 \\
\hline WA107 & $\mathrm{P} 124$ & 42 & 10.65 & 119 & 54.32 & 4575.4 & 979924.43 & -20.43 & 0.13 & 3.16 & -174.68 & -164.86 \\
\hline WA108 & P124 & 42 & 10.65 & 119 & 54.37 & 4578.7 & 979924.68 & -19.87 & 0.18 & 3.30 & -174.09 & -164.27 \\
\hline WA109 & $\mathrm{P} 124$ & 42 & 10.65 & 119 & 54.40 & 4582.7 & 79924.66 & -19.52 & 0.22 & 3.40 & -173.78 & -163.96 \\
\hline WA110 & $\mathrm{P} 124$ & 42 & 10.65 & 119 & 54.45 & 4590.5 & 979924.52 & -18.92 & 0.25 & 3.51 & -173.34 & -163.50 \\
\hline WA111 & $\mathrm{P} 124$ & 42 & 10.65 & 119 & 54.48 & 4595.6 & 979924.39 & -18.57 & 0.40 & 3.70 & -172.96 & -163.13 \\
\hline WA112 & $\mathrm{P} 124$ & 42 & 10.65 & 119 & 54.53 & 4607.2 & 979923.93 & -17.94 & 0.39 & 3.75 & -172.68 & -162.83 \\
\hline WA113 & $\mathrm{P} 124$ & 42 & 10.65 & 119 & 54.56 & 4612.4 & 979923.71 & -17.68 & 0.48 & 3.89 & -172.47 & -162.61 \\
\hline WA114 & $\mathrm{P} 124$ & 42 & 10.65 & 119 & 54.60 & 4619.0 & 979923.47 & -17.30 & 0.56 & 4.03 & -172.17 & -162.31 \\
\hline WA115 & $\mathrm{P} 124$ & 42 & 10.65 & 119 & 54.64 & 4624.2 & 979923.35 & -16.93 & 0.68 & 4.21 & -171.79 & -161.93 \\
\hline WA116 & $\mathrm{P} 124$ & 42 & 10.64 & 119 & 54.68 & 4628.6 & 979923.14 & -16.71 & 0.89 & 4.46 & -171.47 & -161.62 \\
\hline WB & $\mathrm{P} 124$ & 42 & 6.86 & 119 & 56.75 & 4492.0 & 979925.59 & -21.44 & 0.46 & 4.40 & -171.59 & -162.03 \\
\hline WB & P124 & 42 & 6.85 & 119 & 56.67 & 4491.6 & 979924.61 & -22.44 & 0.21 & 3.84 & -173.13 & -163.54 \\
\hline WB & $\mathrm{P} 124$ & 42 & 6.85 & 119 & 56.57 & 4491.3 & 9923.01 & -23.47 & 0.09 & 3.39 & -174.60 & -104.90 \\
\hline WB & $\mathrm{P} 124$ & 42 & 6.84 & 119 & 56.49 & 4490.4 & 979922.68 & -24.47 & 0.04 & 3.09 & -175.87 & -166.23 \\
\hline WB & $\mathrm{P} 124$ & 42 & 6.84 & 119 & 56.42 & 4491.2 & 979921.84 & -25.24 & 0.01 & 2.87 & -176.89 & -167.24 \\
\hline WB & $\mathrm{P} 124$ & 42 & 6.84 & 119 & 56.33 & 4491.1 & 979921.01 & -26.08 & 0.01 & 2.64 & -177.96 & -168.29 \\
\hline WB & $\mathrm{P} 124$ & 42 & 6.84 & 119 & 56.26 & 4490.8 & 979920.43 & -26.68 & 0.01 & 2.48 & -178.71 & -169.03 \\
\hline WB & $\mathrm{P} 124$ & 42 & 6.84 & 119 & 56.18 & 4490.8 & 979919.92 & -27.19 & 0.01 & 2.31 & -179.38 & -169.69 \\
\hline WB & P424 & 42 & 6.84 & 119 & 56.11 & 4491.1 & 979919.37 & -27.72 & 0.01 & 2.19 & -180.05 & -170.35 \\
\hline WB 10 & $\mathrm{P} 124$ & 42 & 6.84 & 119 & 56.03 & 4490.6 & 979918.93 & -28.20 & 0.01 & 2.06 & -180.64 & -170.93 \\
\hline WB 11 & $\mathrm{P} 124$ & 42 & 6.84 & 119 & 55.96 & 4490.6 & 979918.63 & -28.50 & 0.01 & 1.96 & -181.04 & -171.33 \\
\hline WB 12 & P124 & 42 & 6.84 & 119 & 55.91 & 4490.8 & 979918.40 & -28.71 & 0.01 & 1.89 & $-181 \cdot 32$ & -171.61 \\
\hline WB 13 & $\mathrm{P} 124$ & 42 & 6.83 & 119 & 55.84 & 4489.8 & 979918.22 & -28.97 & 0.01 & 1.81 & -181.64 & -171.92 \\
\hline WB 14 & $\mathrm{P} 124$ & 42 & 6.83 & 119 & 55.78 & 4489.8 & 979918.02 & -29.17 & 0.01 & 1.74 & -181.91 & -172.18 \\
\hline WB 15 & $\mathrm{P} 124$ & 42 & 6.83 & 119 & 55.71 & 4489.1 & 979917.92 & -29.34 & 0.01 & 1.67 & $-182 \cdot 12$ & -172.40 \\
\hline WB 16 & $\mathrm{P} 124$ & 42 & 6.83 & 119 & 55.66 & 4489.2 & 979917.80 & -29.45 & 0.01 & 1.62 & -182.28 & -172.55 \\
\hline WB 17 & $\mathrm{P} 124$ & 42 & 6.83 & 119 & 55.61 & 4490.0 & 979917.66 & -29.51 & 0.01 & 1.57 & -182.42 & -172.69 \\
\hline WB 18 & $\mathrm{P} 124$ & 42 & 6.83 & 119 & 55.56 & 4490.0 & 979917.62 & -29.55 & 0.01 & 1.52 & -182.51 & -172.77 \\
\hline WB 19 & $\mathrm{P} 124$ & 42 & 6.83 & 119 & 55.49 & 4490.1 & 979917.65 & -29.52 & 0.01 & 1.47 & -182.53 & -172.79 \\
\hline WB 20 & $\mathrm{P} 124$ & 42 & 6.83 & 119 & 55.43 & 4490.2 & 979917.70 & -29.46 & 0.01 & 1.43 & -182.52 & -172.77 \\
\hline WB 21 & $\mathrm{P} 124$ & 42 & 6.83 & 119 & 55.36 & 4489.6 & 979917.82 & -29.39 & 0.01 & 1.39 & -182.47 & -172.72 \\
\hline WB 22 & $\mathrm{P} 124$ & 42 & 6.83 & 119 & 55.31 & 4489.6 & 979917.96 & -29.25 & 0.01 & 1.35 & -182.36 & -172.61 \\
\hline
\end{tabular}


TABLE 1--CONTINUED

\begin{tabular}{|c|c|c|c|c|c|c|c|c|c|c|c|c|c|}
\hline \multirow{2}{*}{\multicolumn{2}{|c|}{ STATION }} & \multirow{3}{*}{ CODE } & \multirow{2}{*}{\multicolumn{2}{|c|}{ LATITUDE }} & \multirow{2}{*}{\multicolumn{3}{|c|}{ LONGITUDE ELEVATION }} & \multirow{3}{*}{$\begin{array}{c}\text { OBSERVED } \\
\text { GRAVITY } \\
\text { MGAI }\end{array}$} & \multirow{3}{*}{$\begin{array}{l}\text { FREE AIR } \\
\text { ANOMALY } \\
\text { MGAL }\end{array}$} & \multirow{3}{*}{\multicolumn{2}{|c|}{$\begin{array}{l}\text { TERRAIN } \\
\text { HAND TOTAL } \\
\text { MGAI }\end{array}$}} & \multirow{3}{*}{\multicolumn{2}{|c|}{\begin{tabular}{|cr} 
BOUGUER & ANOMALY \\
2.67 & 2.50
\end{tabular}}} \\
\hline & & & & & & & & & & & & & \\
\hline & & & DEG & MIN & DEG & MIN & FEET & & & & & & \\
\hline & & & & & & & & & & & & & \\
\hline WB & 23 & $\mathrm{P} 124$ & 42 & 6.83 & 119 & 55.26 & 4489.3 & 979918.13 & -29.11 & 0.01 & 1.33 & -182.24 & -172.49 \\
\hline WB & 24 & $\mathrm{P} 124$ & 42 & 6.83 & 119 & 55.18 & 4489.3 & 979918.29 & -28.95 & 0.01 & 1.28 & -182.12 & -172.37 \\
\hline WB & 25 & $\mathrm{P} 124$ & 42 & 6.83 & 119 & 55.14 & 4489.2 & 979918.41 & -28.84 & 0.01 & 1.26 & -182.03 & -172.28 \\
\hline WB & 26 & $\mathrm{P} 124$ & 42 & 6.83 & 119 & 55.07 & 4489.0 & 979918.50 & -28.77 & 0.01 & 1.23 & -181.99 & -172.23 \\
\hline WB & 27 & $\mathrm{P} 124$ & 42 & 6.83 & 119 & 55.02 & 4489.0 & 979918.56 & -28.71 & 0.01 & 1.21 & -181.95 & -172.19 \\
\hline WB & 28 & $\mathrm{P} 124$ & 42 & 6.83 & 119 & 54.97 & 4489.0 & 979918.56 & -28.71 & 0.01 & 1.18 & -181.97 & -172.21 \\
\hline WB & 29 & $\mathrm{P} 124$ & 42 & 6.83 & 119 & 54.91 & 4488.9 & 979918.54 & -28.74 & 0.01 & 1.16 & -182.02 & -172.26 \\
\hline WB & 30 & $\mathrm{P} 124$ & 42 & 6.83 & 119 & 54.84 & 4489.5 & 979918.42 & -28.80 & 0.01 & 1.13 & -182.13 & -172.37 \\
\hline WB & 31 & $\mathrm{P} 124$ & 42 & 6.83 & 119 & 54.78 & 4488.9 & 979918.44 & -28.84 & 0.01 & 1.11 & -182.18 & -172.41 \\
\hline WB & 32 & P124 & 42 & 6.83 & 119 & 54.72 & 4489.3 & 979918.21 & -29.03 & 0.01 & 1.09 & -182.40 & -172.63 \\
\hline WB & 33 & $\mathrm{P} 124$ & 42 & 6.83 & 119 & 54.67 & 4488.9 & 979918.15 & -29.13 & 0.01 & 1.07 & -182.50 & -172.74 \\
\hline WB & 34 & $\mathrm{P} 124$ & 42 & 6.83 & 119 & 54.60 & 4489.0 & 979918.02 & -29.25 & 0.01 & 1.04 & -182.65 & -172.89 \\
\hline WB & 35 & $\mathrm{P} 124$ & 42 & 6.83 & 119 & 54.53 & 4489.0 & 979917.86 & -29.41 & 0.01 & 1.02 & -182.83 & -173.07 \\
\hline WB & 36 & $\mathrm{P} 124$ & 42 & 6.83 & 119 & 54.47 & 4489.9 & 979917.76 & -29.42 & 0.01 & 1.00 & -182.89 & $-173 \cdot 12$ \\
\hline WB & 37 & $\mathrm{P} 123$ & 42 & 6.83 & 119 & 54.41 & 4489.9 & 979917.55 & -29.63 & 0.01 & 0.99 & -183.12 & -173.35 \\
\hline WB & 38 & $\mathrm{P} 124$ & 42 & 6.82 & 119 & 54.33 & 4490.0 & 979917.51 & -29.65 & 0.01 & 0.97 & -183.16 & -173.39 \\
\hline WB & 39 & $\mathrm{P} 124$ & 42 & 6.81 & 119 & 54.27 & 4490.5 & 979917.40 & -29.70 & 0.01 & 0.95 & -183.25 & -173.47 \\
\hline WB & 40 & $\mathrm{P} 124$ & 42 & 6.82 & 119 & 54.19 & 4490.4 & 979917.29 & -29.83 & 0.01 & 0.93 & -183.39 & -173.61 \\
\hline WB & 41 & $\mathrm{P} 124$ & 42 & 6.82 & 119 & 54.12 & 4490.8 & 979917.14 & -29.94 & 0.01 & 0.92 & -183.53 & -173.75 \\
\hline WB & 42 & P124 & 42 & 6.82 & 119 & 54.06 & 4489.8 & 979917.14 & -30.04 & 0.01 & 0.91 & -183.61 & -173.83 \\
\hline WB & 43 & $\mathrm{P} 124$ & 42 & 6.79 & 119 & 54.00 & 4489.2 & 979917.13 & -30.06 & 0.01 & 0.89 & -183.62 & -173.84 \\
\hline WB & 44 & $\mathrm{P} 124$ & 42 & 6.76 & 119 & 53.96 & 4489.9 & 979916.99 & -30.09 & 0.01 & 0.88 & -183.68 & -173.91 \\
\hline WB & 45 & P124 & 42 & 6.73 & 119 & 53.90 & 4490.1 & 979916.95 & -30.06 & 0.01 & 0.87 & -183.68 & -173.89 \\
\hline WB & 46 & $\mathrm{P} 124$ & 42 & 6.69 & 119 & 53.85 & 4489.0 & 979916.92 & -30.14 & 0.01 & 0.86 & -183.23 & -173.95 \\
\hline WB & 47 & $\mathrm{P} 124$ & 42 & 6.66 & 119 & 53.80 & 4489.0 & 979916.89 & -30.12 & 0.01 & 0.85 & -183.72 & -173.94 \\
\hline WB & 48 & $\mathrm{P} 124$ & 42 & 6.63 & 119 & 53.75 & 4489.2 & 979916.91 & -30.04 & 0.01 & 0.84 & -183.65 & -173.87 \\
\hline WB & 49 & $\mathrm{P} 124$ & 42 & 6.59 & 119 & 53.69 & 4489.8 & 979916.87 & -29.96 & 0.01 & 0.83 & -183.60 & -173.82 \\
\hline WB & 50 & $\mathrm{P} 124$ & 42 & 6.56 & 119 & 53.66 & 4489.9 & 979916.90 & -29.88 & 0.01 & 0.82 & -183.53 & -173.75 \\
\hline WB & 51 & $\mathrm{P} 124$ & 42 & 6.53 & 119 & 53.61 & 4489.8 & 979916.91 & -29.83 & 0.01 & 0.82 & -183.49 & -173.70 \\
\hline WB & 52 & P124 & 42 & 6.51 & 119 & 53.57 & 4489.7 & 979916.84 & -29.88 & 0.01 & 0.81 & -183.54 & -173.75 \\
\hline WB & 53 & $\mathrm{P} 124$ & 42 & 6.48 & 119 & 53.52 & 4488.9 & 979916.77 & -29.98 & 0.01 & 0.81 & -183.61 & -173.83 \\
\hline WB & 54 & $\mathrm{P} 124$ & 42 & 6.46 & 119 & 53.47 & 4488.5 & 979916.74 & -30.02 & 0.01 & 0.80 & -183.64 & -173.86 \\
\hline WB & 55 & $\mathrm{P} 124$ & 42 & 6.43 & 119 & 53.43 & 4489.5 & 979916.64 & -29.98 & 0.01 & 0.80 & -183.64 & -173.86 \\
\hline WB & 56 & $\mathrm{P} 123$ & 42 & 6.40 & 119 & 53.37 & 4488.0 & 979916.59 & -30.13 & 0.01 & 0.80 & -183.75 & -173.97 \\
\hline WC & 2 & $\mathrm{P} 124$ & 42 & 18.71 & 119 & 52.68 & 4481.6 & 979951.39 & -14.36 & 0.38 & 3.99 & -164.56 & -155.00 \\
\hline WC & 3 & $\mathrm{P} 124$ & 42 & 18.71 & 119 & 52.72 & 4487.1 & 979950.92 & -14.31 & 0.54 & 4.24 & -164.45 & -154.90 \\
\hline WC & 4 & $\mathrm{P} 124$ & 42 & 18.71 & 119 & 52.62 & 4479.2 & 979951.73 & -14.24 & 0.24 & 3.69 & -164.66 & -155.08 \\
\hline WC & 5 & $\mathrm{P} 124$ & 42 & 18.71 & 119 & 52.58 & 4478.5 & 979951.86 & -14.18 & 0.18 & 3.53 & -164.74 & -155.15 \\
\hline $\mathrm{WC}$ & 6 & $\mathrm{P} 124$ & 42 & 18.71 & 119 & 52.55 & 4478.0 & 979951.98 & -14.11 & 0.13 & 3.41 & -164.77 & -155.18 \\
\hline WC & 7 & P124 & 42 & 18.71 & 119 & 52.49 & 4477.1 & 979952.16 & -14.01 & 0.09 & 3.24 & -164.81 & -155.21 \\
\hline WC & 8 & $\mathrm{P} 124$ & 42 & 18.71 & 119 & 52.44 & 4476.9 & 979952.17 & -14.02 & 0.04 & 3.08 & -164.97 & -155.36 \\
\hline WC & 9 & $\mathrm{P} 124$ & 42 & 18.71 & 119 & 52.38 & 4476.4 & 979952.12 & -14.12 & 0.02 & 2.94 & -165.20 & -155.58 \\
\hline WC & 10 & $\mathrm{P} 124$ & 42 & 18.71 & 119 & 52.32 & 4476.6 & 979952.02 & -14.20 & 0.01 & 2.81 & -165.41 & -155.78 \\
\hline WC & 11 & $\mathrm{P} 124$ & 42 & 18.71 & 119 & 52.27 & 4476.9 & 979952.18 & -14.01 & 0.01 & 2.72 & -165.32 & -155.69 \\
\hline WC & 12 & $\mathrm{P} 124$ & 42 & 18.71 & 119 & 52.22 & 4477.4 & 979952.21 & -13.93 & 0.01 & 2.64 & -165.34 & -155.70 \\
\hline WC & 13 & $\mathrm{P} 124$ & 42 & 18.71 & 119 & 52.17 & 4476.2 & 979952.26 & -14.00 & 0.01 & 2.57 & -165.44 & -155.80 \\
\hline WC & 14 & $\mathrm{P} 124$ & 42 & 18.71 & 119 & 52.12 & 4478.6 & 979952.07 & -13.96 & 0.01 & 2.49 & -165.56 & -155.91 \\
\hline WC & 15 & $\mathrm{P} 124$ & 42 & 18.71 & 119 & 52.07 & 4478.0 & 979952.09 & -14.00 & 0.01 & 2.43 & -165.64 & -155.98 \\
\hline WC & 16 & $\mathrm{P} 124$ & 42 & 18.71 & 119 & 52.02 & 4477.6 & 979952.13 & -13.99 & 0.01 & 2.38 & -165.67 & -156.01 \\
\hline WC & 17 & $\mathrm{P} 124$ & 42 & 18.71 & 119 & 51.97 & 4477.8 & 979952.06 & -14.04 & 0.01 & 2.33 & -165.78 & -156.12 \\
\hline
\end{tabular}


TABLE 1--CONTINUED

\begin{tabular}{|c|c|c|c|c|c|c|c|c|c|c|c|c|c|}
\hline & & & & & & & & \multirow{3}{*}{$\begin{array}{l}\text { OBSERVED } \\
\text { GRAVITY } \\
\text { MGAL }\end{array}$} & \multirow{3}{*}{$\begin{array}{l}\text { FRE AIR } \\
\text { ANOMALY } \\
\text { MGAL }\end{array}$} & \multirow{3}{*}{\multicolumn{2}{|c|}{$\begin{array}{c}\text { TERRAIN } \\
\text { HAND TOTAL } \\
\text { MGAL }\end{array}$}} & \multirow{3}{*}{\multicolumn{2}{|c|}{$\begin{array}{cc}\text { BOUGUER } & \text { ANOMALY } \\
2.67 & 2.50 \\
\text { MGAL }\end{array}$}} \\
\hline STAT & TOA & $\mathrm{CODF}$ & \multicolumn{2}{|c|}{ LATTTUDE } & \multicolumn{3}{|c|}{ IONGTTUDE FIEVATTON } & & & & & & \\
\hline & & & DEG & MIN & $\mathrm{DEG}$ & MIN & & & & & & & \\
\hline WC & 18 & $\mathrm{P} 124$ & 42 & 18.71 & 119 & 51.91 & 4476.9 & 2.11 & -14.08 & 0.01 & 2.27 & -165.84 & -156.18 \\
\hline $\mathrm{WC}$ & 19 & P124 & 42 & 18.71 & 119 & 51.85 & 4476.7 & 979952.15 & -14.06 & 0.01 & 2.22 & -165.86 & -156.20 \\
\hline $\mathrm{WC}$ & 20 & $\mathrm{P} 124$ & 42 & 18.71 & 119 & 51.79 & 4477.2 & 979951.95 & -14.21 & 0.01 & 2.17 & -166.08 & -156.41 \\
\hline $\mathrm{WC}$ & 21 & $\mathrm{P} 124$ & 42 & 18.71 & 119 & 51.73 & 4477.3 & 979951.81 & -14.34 & 0.01 & 2.13 & -166.26 & -156.59 \\
\hline $\mathrm{WC}$ & 22 & $\mathrm{P} 124$ & 42 & 18.71 & 119 & 51.69 & 4477.5 & 979951.62 & -14.51 & 0.01 & 2.10 & -166.46 & -156.79 \\
\hline WC & 23 & $\mathrm{P} 124$ & 42 & 18.71 & 119 & 51.64 & 4477.8 & 979951.14 & -14.96 & 0.01 & 2.07 & -166.95 & -157.27 \\
\hline
\end{tabular}


Table 2. Location description code (digit one).

[The number after the alphabetical code indicates the total number of gravity stations for which the code was used.]

B 45 On level-line benchmark incorporated into U.S. Geological Survey vertical control system.

N 14 Near benchmark.

P 188 Location of surveyed elevation.

X 5 Near location markers such as section corners.

D 1 Near assumed location of any of the above markers that were destroyed or not found.

R 1 Lake or reservoir elevation determined from leveling to benchmark.

F 32 Near a location with or without a marker at which a surveyed elevation is indicated on a published topographic map.

G 58 Near a location (on a manuscript map or a published map) at which spot elevations are determined by photogrammetry or near a doubtful F-location.

W 12 Near edge of lake or canal; interpolated elevation or elevation given for water at unknown height relative to present level.

Table 3. Accuracy of elevations (digit two).

[The number after the numerical code indicates the total number of stations for which the code was used. Note that uncertainty of horizontal location tends to reduce the elevation accuracy].

Code $\quad$ Number $\quad \frac{\text { Accuracy }}{\text { (feet) }} \quad$ Examples

$1230 \quad 0.1 \quad$ On benchmark; surveyed elevation

$2 \quad 10 \quad 0.5 \quad$ Elevation difference hand-leveled to nearby benchmark

$3 \quad 7 \quad 1 \quad$ Near benchmark or checked water level

$42 \quad 2$ Near assumed location of benchmark that was not found

$5 \quad 70 \quad 5 \quad$ Near location with 10-foot contour interval

6 $36 \quad 10 \quad$ Photogrammetric elevation on map with 20-foot contour interval

$7 \quad 1 \quad 20 \quad$ Uncertain location of spot elevation point 
Table 4. Accuracy of horizontal location (digit three).

[The number after the numerical code indicates the total number of stations for which the code was used.]

\begin{tabular}{|c|c|c|c|}
\hline Code & $\underline{\text { Number }}$ & $\frac{\text { Accuracy }}{(\text { feet })}$ & Examples \\
\hline 2 & 252 & 84 & $\begin{array}{l}\text { Near section corners and benchmarks; surveyed } \\
\text { locations }\end{array}$ \\
\hline 3 & 80 & 210 & $\begin{array}{l}\text { Near road intersection, stream crossings, } \\
\text { hillcrests }\end{array}$ \\
\hline 4 & 22 & 420 & Road curve; uncertain spot elevation location \\
\hline 5 & 2 & 840 & $\begin{array}{l}\text { Location depends on odometer measurement or } \\
\text { other estimate }\end{array}$ \\
\hline
\end{tabular}

Table 5. Accuracy of observed gravity (digit four).

[The number after the numerical code indicates the total number of stations for which the code was used. Accuracies are relative to the value at the Adel base station.]

Code Number Accuracy Examples

(mgal)

$2 \quad 30.02$ Reading repeated several times

$3 \quad 8 \quad 0.05 \quad$ Repeated reading

$4 \quad 345 \quad 0.10 \quad$ Non-repeated reading 


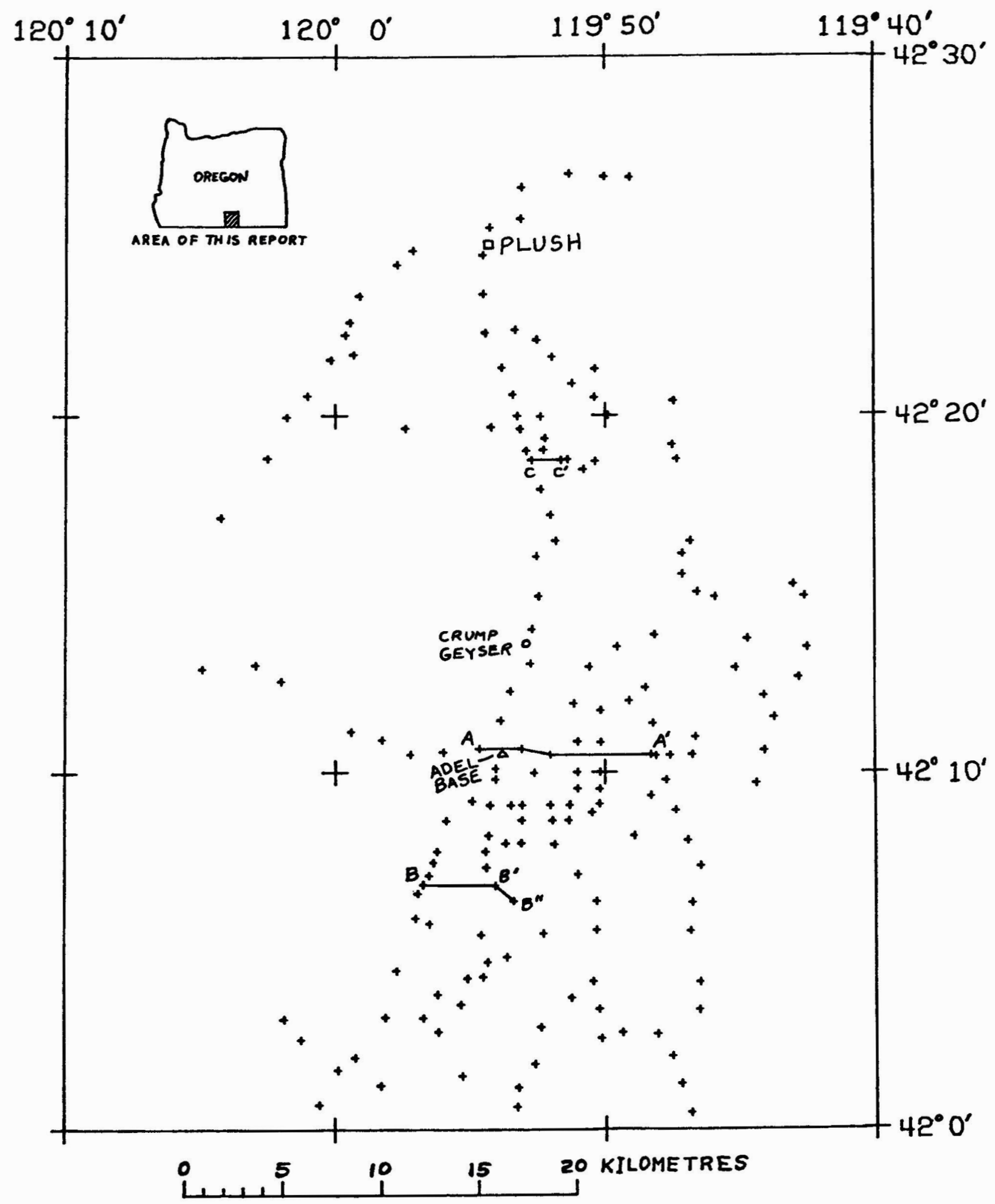

Figure 1. Location of gravity stations and traverses. 


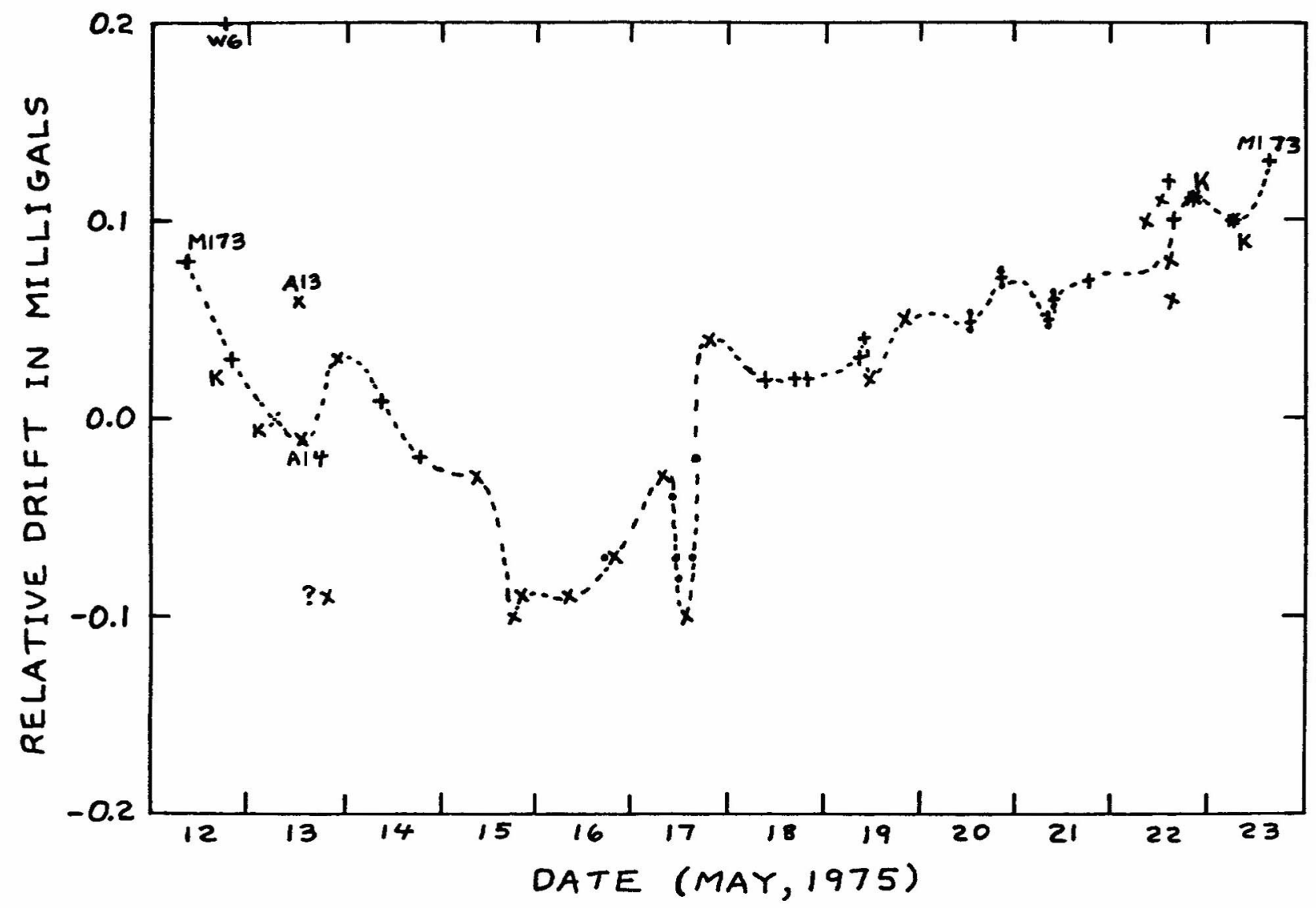

SYMBOLS USED
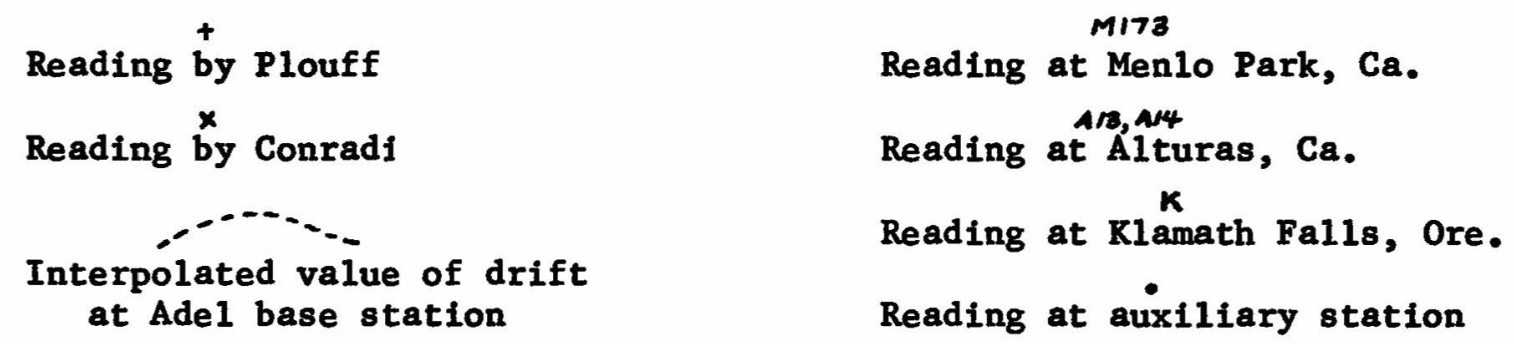

Figure 2. Gravity drift curve relative to Adel base station. 